\title{
Nicotine Binding and Nicotinic Receptor Subunit RNA after Chronic Nicotine Treatment
}

\author{
Michael J. Marks,, James R. Pauly,, Stefan D. Gross,, Evan S. Deneris,, ${ }^{3, a}$ Irm Hermans-Borgmeyer, ${ }^{3, b}$ Stephen \\ F. Heinemann, ${ }^{3}$ and Allan C. Collins ${ }^{1,2}$ \\ 1'Institute for Behavioral Genetics and ${ }^{2}$ Department of Psychology, University of Colorado, Boulder, Colorado 80309 and \\ ${ }^{3}$ Molecular Neurobiology Laboratory, The Salk Institute, La Jolla, California 92037
}

\begin{abstract}
DBA mice were chronically treated with nicotine by continuous intravenous infusion of $4.0 \mathrm{mg} / \mathrm{kg} / \mathrm{hr}$ for $10 \mathrm{~d}$. Drugtreated mice were tolerant to the acute effects of nicotine on locomotor activity and body temperature. The effect of chronic treatment on the amount of $\mathrm{L}^{3} \mathrm{H}$-nicotine binding and RNA encoding for $\alpha_{4}$, the most widely expressed nicotinic $\alpha$-subunit, was measured in three brain regions. Chronic treatment increased $\mathrm{L}^{3} \mathrm{H}-$-nicotine binding in cortex and midbrain but had no effect in cerebellum. In contrast, chronic treatment had no effect on the levels of mRNA encoding for $\alpha_{4}$ in any of the three brain regions. Subsequently brains were sectioned and L-3H-nicotine binding was measured using quantitative autoradlographic methods. In addition, the relative amounts of mRNA for the major nicotinic receptor subunits $\left(\alpha_{4}\right.$ and $\left.\beta_{2}\right)$, as well as for three additional minor subunits $\left(\alpha_{2}, \alpha_{3}\right.$, and $\left.\alpha_{5}\right)$, were determined by in situ hybridization histochemistry followed by quantitation of image intensity. Chronic nicotine treatment resulted in increases in the amount of L-3H-nicotine binding in many but not all brain areas measured. In contrast, chronic treatment had little effect on the intensity of the hybridization signal for the nicotinic subunit mRNA. The results suggest that chronic treatment with nicotine under conditions resulting in maximal steady-state increases in L- ${ }^{3} \mathrm{H}-n$ icotine binding has little effect on RNA levels encoding any of four nicotinic $\alpha$-subunits and the $\beta_{2}$-subunit.
\end{abstract}

The continued use of tobacco products results in the development of many signs of tolerance (Surgeon General, 1988). The physiological and biochemical changes that underlie the development of tolerance to nicotine, the principle active component of tobacco, are not fully understood. However, chronic exposure to nicotine results in an increase in the density of binding sites

\footnotetext{
Received Sept. 27, 1991; revised Feb. 12, 1992; accepted Feb. 18, 1992.

This research was supported by Grants DA-03194 and DA-00116 from NIDA and Grants AA-08388 and AA-06391 from NIAAA to the authors in Boulder and NIH Jacob Javits Investigator Award from NIH, Tobacco-Related Disease Research Program, University of California, and MDA research grant to Dr. Heinemann. We thank Dr. Scott Rogers for helpful comments on the manuscript, Dr. Jim Boulter for useful discussions, and Mike Adler for supplying the $a_{5}$ construct.

Correspondence should be addressed to Michael Marks, Institute for Behavioral Genetics, Campus Box 447, University of Colorado, Boulder, CO 80309.

a Present address: Department of Neuroscience, School of Medicine, Case-Western Reserve University, Cleveland, $\mathrm{OH} 44106$.

b Present address: ZMNH-II, Universitat Hamburg, Hamburg, Germany. Copyright (C) 1992 Society for Neuroscience $0270-6474 / 92 / 122765-20 \$ 05.00 / 0$
}

for putative nicotinic receptors in the brains of mice (Marks et al., 1983), rats (Schwartz and Kellar, 1983), and humans (Benwell et al., 1988). Studies from our laboratory using the DBA/2 mouse strain have shown that the sites labeled with $\mathrm{L}^{-3} \mathrm{H}$-nicotine increase with treatment time (Marks et al., 1985) and treatment dosage (Marks et al., 1983, 1986a) and decrease to control levels following withdrawal (Marks et al., 1985) in patterns closely approximating the changes in sensitivity to nicotine.

Characterization of putative nicotinic receptors in brain using receptor binding techniques indicates that at least two major classes of binding sites exist: one labeled by high-affinity binding of $\mathrm{L}^{-3} \mathrm{H}$-nicotine or ${ }^{3} \mathrm{H}-\mathrm{ACh}$ and a second labeled with $\alpha-{ }^{125} \mathrm{I}$ bungarotoxin (Clarke et al., 1985; Marks et al., 1986b). The application of molecular techniques to the study of brain nicotinic receptors has demonstrated that the heterogeneity of these receptors is much greater than indicated by binding studies. The nicotinic receptor in brain seems to be composed of only two types of subunit, $\alpha$ and $\beta$ (for review, see Luetje et al., 1990). Four $\alpha$-subunits and three $\beta$-subunits have been identified in rat brain, to date (Boulter et al., 1986, 1990; Goldman et al., 1987; Deneris et al., 1988, 1989; Wada et al., 1988; Duvoisin et al., 1989). As is the case with the muscle receptors, the $\alpha$-subunits interact with agonists such as $\mathrm{ACh}$ or nicotine. The distribution of RNA encoding for several of these subunits in brain indicates that each one has a unique localization (Goldman et al., 1987; Deneris et al., 1989; Duvoisin et al., 1989; Wada et al., 1989; Boulter et al., 1990). Functional ion channels have been reconstituted using Xenopus oocytes, in which the combination of in vitro transcripts of one $\alpha\left(\alpha_{2}, \alpha_{3}\right.$, or $\left.\alpha_{4}\right)$ with those of a single $\beta\left(\beta_{2}\right.$ or $\left.\beta_{4}\right)$ results in the expression of agonistsensitive ion channels (Boulter et al., 1987; Duvoisin et al., 1989; Papke et al., 1989). Characterization of $\alpha$-bungarotoxin binding components in the CNS has also begun, and two related $\alpha$-subunits have been identified in chick brain (Couturier et al., 1990; Schoepfer et al., 1990).

One receptor subtype $\left(\alpha_{4}, \beta_{2}\right)$ appears to account for most $(>90 \%)$ of the nicotine binding in rat brain (Whiting and Lindstrom, 1986; Whiting et al., 1987; Lindstrom et al., 1990), and a cell line transfected with chick $\alpha_{4}$ and $\beta_{2}$ genes expresses highaffinity nicotine binding (Whiting et al., 1991). In addition, the similarity in the distribution of $\mathrm{L}^{-3} \mathrm{H}$-nicotine binding sites (Clarke et al., 1985) and of sites labeled with monoclonal antibody (MAb) 270, which recognizes the $\beta_{2}$-subunit of nicotinic ACh receptors (Swanson et al., 1987), is consistent with that assignment of the $\beta_{2}$-subunit as the primary structural subunit. Fur- 
thermore, the distribution of RNA encoding both the $\alpha_{4}$ - and $\beta_{2}$-subunits of the nicotinic ACh receptor in rat brain is similar to the distribution of both $\mathrm{L}^{-}{ }^{3} \mathrm{H}$-nicotine and MAb 270 binding sites. The correspondence is not perfect, however, suggesting that some $\mathrm{L}^{-3} \mathrm{H}$-nicotine binding sites encoded by $\alpha_{4}$ are presynaptic or that some $\mathrm{L}^{-3} \mathrm{H}$-nicotine binding sites may be encoded by other $\alpha$-genes. It is also possible that the subunits coded by the other members of this complex gene family are not detected by $\mathrm{L}^{-3} \mathrm{H}$-nicotine. Clearly, the receptors encoded by the other genes may be important in influencing responsiveness to nicotine, and changes in these receptors after nicotine treatment may be important in modulating tolerance to the effects of nicotine.

The present study was undertaken to investigate whether the changes in $\mathbf{L}^{-3} \mathrm{H}$-nicotine binding sites observed in mice after chronic exposure to nicotine may be due to changes in the levels of mRNA for four $\alpha$-subunits and the major $\beta$-subunit that encode the protein subunits of the nicotinic ACh receptor in brain.

\section{Materials and Methods}

Materials. Uridine triphosphate $\left(\alpha^{-35} \mathrm{~S}\right)$ and uridine triphosphate $\left(\alpha^{-32} \mathbf{P}\right)$ were obtained from New England Nuclear (Boston, MA). L-Nicotine (methyl- ${ }^{3} \mathrm{H}$ ) and Hyperfilm- ${ }^{3} \mathrm{H}$ were obtained from Amersham Corp. (Arlington Heights, IL). Adenosine triphosphate, cytosine triphosphate, guanosine triphosphate, and RNase A were purchased from BoehringerMannheim (Indianapolis, IN). The enzymes EcoRI, HindIII, SP6 RNA polymerase, T3 RNA polymerase, and RQ1 DNase, as well as the RNasin, were obtained from Promega Corp. (Madison, WI). Dextran sulfate was purchased from Pharmacia (Uppsala, Sweden) and formamide from Fluka Chemical Corp. (Ronkonkoma, NY). DPX mountant was purchased from BDH Lid. (Poole, England). Ammonium acetate, morpholine propane sulfonic acid, Tris, Tris hydrochloride, 1-piperazincdiethanesulfonic acid (PIPES), sodium carbonate, sodium bicarbonate, gelatin, RNase T1, yeast tRNA, total yeast RNA, triethanolamine, sodium chloride, sodium citrate, phenol, magnesium chloride, dithiothreitol (DTT), disodium EDTA, Denhardt's solution, acetic anhydride, poly-L-lysine, diethylpyrocarbonate, sodium hydroxide, trichloroacetic acid (TCA), guanidinium thiocyanate, and sodium phosphate were obtained from Sigma Chemical Co. (St. Louis, MO). Microscope slides and coverslips were products of Richard-Allen (Richfield, MI).

Mice. Female DBA/2J/Ibg mice were used in this study. Animals were between 60 and $90 \mathrm{~d}$ of age at the time of surgery. Before surgery, the mice were housed five per cage and were allowed free access to food (Wayne Lab Blox) and water. A $12 \mathrm{hr}$ light/12 hr dark cycle was maintained (lights on 7 A.M. to 7 P.M.).

Surgery. A cannula made of Silastic tubing was implanted in the right jugular vein of each mouse using the method of Barr et al. (1979). After surgery, mice were transferred to individual treatment cages and cannulas were attached to polyethylene tubing connected to a syringe mounted on a Harvard infusion pump (Harvard Instruments, South Natick, MA). Continuous infusion with sterile isotonic saline was then begun (flow rate, $35 \mu \mathrm{l} / \mathrm{hr}$ ).

Chronic nicotine treatment. After a $2 \mathrm{~d}$ recovery period, saline infusion was continued for control mice and nicotine treatment was initiated for drug-treated mice. The final treatment dosage of $4.0 \mathrm{mg} / \mathrm{kg} / \mathrm{hr}$ was attained by initiating infusion at a rate of $1.0 \mathrm{mg} / \mathrm{kg} / \mathrm{hr}$ and increasing the dosage by $1.0 \mathrm{mg} / \mathrm{kg} / \mathrm{hr}$ per day until the final infusion rate was achieved. Mice were maintained at the $4.0 \mathrm{mg} / \mathrm{kg} / \mathrm{hr}$ dose for a total of $10 \mathrm{~d}$.

Measurement of acute responsiveness to nicotine. On the tenth day of treatment with $4.0 \mathrm{mg} / \mathrm{kg} / \mathrm{hr}$ nicotine (thirteenth day of drug treatment), each mouse was tested for sensitivity to nicotine. Two hours after cessation of treatment, saline was injected intraperitoneally and activity in a Y-maze and body temperature were measured. Two hours after completion of the baseline measurement, each mouse was injected intraperitoneally with $1.0 \mathrm{mg} / \mathrm{kg}$ nicotine and activity and temperature were measured again. Injection vehicle was sterile isotonic saline, and the injection volume was $0.01 \mathrm{ml} / \mathrm{gm}$. The $\mathrm{Y}$-maze test was conducted for $3 \mathrm{~min}$ beginning $5 \mathrm{~min}$ after injection of either saline or nicotine. Body temperature was measured $15 \mathrm{~min}$ after injection using a Thermalert rectal thermometer (Bailey Instruments, Saddlebrook, NJ). The Y-maze and body temperature tests were used to evaluate responsiveness to nicotine because these measures have provided reliable estimates of initial sensitivity to nicotine (Marks et al., 1989) and tolerance development (Marks et al., 1986a). Preliminary studies with untreated animals indicated that measurement of responses of a mouse twice in a day (one saline and one nicotine test) gave results virtually identical to those obtained using animals tested only with nicotine or with saline. The double testing of the mice allowed measurement of responses after acute injection of saline and nicotine in each mouse.

At the completion of the tolerance tests, mice were returned to their treatment cages and infusion was continued.

Tissue preparation. The day following the tolerance tests, each mouse was removed from its infusion cage and its cannula was checked for free flow. The mouse was then killed by cervical dislocation, and its brain was rapidly removed and frozen by immersion in isopentane $\left(-35^{\circ} \mathrm{C}\right)$ and stored at $-70^{\circ} \mathrm{C}$ until sectioning.

Brains were sectioned using an IEC cryostatic microtome (International Equipment Corp., Needham Heights, MA) refrigerated to $-16^{\circ} \mathrm{C}$. Coronal sections $14 \mu \mathrm{m}$ thick were thaw mounted onto $25 \mathrm{~mm} \times 75$ $\mathrm{mm}$ glass microscope slides that had been treated both with gelatin/ chrome alum and poly-L-lysine (Simmons et al., 1989). Nine sets of serial sections (approximately 80 sections per set) were collected from each mouse so that ligand binding and in situ hybridizations could be performed for each mouse. At the completion of the sectioning, slides were dried under vacuum and stored, dessicated, at $-70^{\circ} \mathrm{C}$ until use.

Nicotine binding for quantitative autoradiography. One set of sections was used to measure the binding of $\mathrm{L}^{-3} \mathrm{H}$-nicotine. The experimental procedures were similar to those reported by Pauly et al. (1989). Briefly, sets of 25 slides were incubated in $200 \mathrm{ml}$ of Krebs-Ringers HEPES $\left(\mathrm{NaCl}, 118 \mathrm{~mm} ; \mathrm{KCl}, 4.8 \mathrm{~mm} ; \mathrm{CaCl}_{2}, 2.5 \mathrm{~mm} ; \mathrm{MgSO}_{4}, 1.2 \mathrm{~mm}\right.$; HEPES, $20 \mathrm{~mm}$; $\mathrm{pH}$ to 7.5 with $\mathrm{NaOH}$ ) for $30 \mathrm{~min}$ at $4^{\circ} \mathrm{C}$ to rinse the tissue and remove endogenous $\mathrm{ACh}$ and/or nicotine remaining from the treatment. The slides were then transferred to $200 \mathrm{ml}$ of Krebs-Ringers HEPES containing $5.1 \mathrm{nM} \mathrm{L}^{-3} \mathrm{H}$-nicotine (Amersham, Arlington Heights, IL; specific activity, $68.0 \mathrm{Ci} / \mathrm{mmol}$ ) and incubated for $90 \mathrm{~min}$ at $4^{\circ} \mathrm{C}$. After the incubation with the radiolabeled nicotine, the slides were washed as follows: Krebs-Ringers HEPES, $2 \times 5 \mathrm{sec} ; 20$ mM HEPES (pH 7.5), $2 \times 5 \mathrm{sec}$; and water, $2 \times 5 \mathrm{sec}$. Wash temperature was $4^{\circ} \mathrm{C}$. The slides were then air dried at room temperature and apposed to Hyperfilm ${ }^{3} \mathrm{H}$ for 6 weeks. Subsequently, 4 week and 8 week exposure times were used to assure that film response was not saturated for areas that bound large amounts of nicotine and to allow sufficient exposure time for areas that bound relatively little nicotine.

Incubation and wash conditions were established from preliminary experiments in which ligand binding was monitored by scintillation counting of counts bound to tissue scraped from slides. The conditions are very similar to those employed in the measurement of binding to tissue homogenates (Marks et al., 1986b). Binding in the presence of 10 $\mu_{\mathrm{M}}$ unlabeled nicotine did not exceed film background.

In situ $R N A$ hybridization. The method for in situ hybridization using riboprobes is identical to that described by Wada et al. (1989) and Simmons et al. (1989), with the exception that the tissue was fixed in vitro, rather than by perfusion in vivo.

Probes were prepared using in vitro transcription and $\alpha{ }^{-35}$ S-UTP as the sole source of UTP. The constructs used to synthesize the probes were $\alpha_{2}$ : clone HYP16(REV) (HYP16 subcloned in pSP64 in antisense orientation relative to the SP6 promoter), linearized with HindIII, synthesized using SP6 RNA polymerase; $\alpha_{3}$ : clone pPCA48E(4), cloned in pSP65, linearized with HindIII, synthesized using SP6 RNA polymerase; $\alpha_{4}$ : clone pHYA23-1E(2), cloned in pSP64, linearized with EcoRI, synthesized using SP6 RNA polymcrasc; $\alpha_{5}$ : clonc PC989 subcloned into pBluescript (generously supplied by M. Adler), linearized with EcoRI, synthesized using T3 RNA polymerase; and $\beta_{2}$ : clone pSP65-49, cloned in pSP65, linearized with HindIII, synthesized using SP6 RNA polymerase. Each synthesis was designed to yield full-length antisense transcripts. Products were analyzed by electrophoresis through denaturing agarose gels. The cRNAs were stored as precipitates in $70 \%$ ethanol at $-20^{\circ} \mathrm{C}$ until use. Hybridizations were performed within $3 \mathrm{~d}$ of probe synthesis. Immediately before hybridization, probes were subjected to alkaline hydrolysis using the method of Cox et al. (1984) to yield products with average sizes of 500 bases. 
On the day of the hybridizations, slides containing tissue sections were removed from the freezer, warmed to room temperature under vacuum, incubated for $15 \mathrm{~min}$ with 4\% paraformaldehyde in PBS (phosphate-buffered saline: $\mathrm{NaCl}, 137 \mathrm{~mm} ; \mathrm{KCl}, 2.5 \mathrm{~mm} ; \mathrm{Na}_{2} \mathrm{HPO}_{4}, 16 \mathrm{~mm}$; and $\mathrm{NaH}_{2} \mathrm{PO}_{4}, 4 \mathrm{~mm} ; \mathrm{pH} 7.4$ ) to fix the tissue. After fixation, the slides were washed three times for $5 \mathrm{~min}$ each in PBS and followed by air drying. After drying, tissue sections were acetylated by incubation for $10 \mathrm{~min}$ with $15 \mathrm{~mm}$ acetic anhydride in $0.1 \mathrm{M}$ triethanolamine, $\mathrm{pH} \mathrm{8.0.}$ Slides were then rinsed for $2 \mathrm{~min}$ in $2 \times \mathrm{SSC}(1 \times \mathrm{SSC}: \mathrm{NaCl}, 150 \mathrm{~mm}$; trisodium citrate, $15 \mathrm{~mm} ; \mathrm{pH}$ to 7.0 with $\mathrm{HCl}$ ) and dehydrated by passage through an ethanol series ( 3 min each: $50 \%, 70 \%, 95 \%, 100 \%$, and $100 \%$ ). After dehydration, the slides were air dried and then stored under vacuum until the hybridization was begun (storage time, 2-4 hr).

${ }^{35} \mathrm{~S}$-radiolabeled cRNA probes, prepared as described above, were dissolved in hybridization buffer (formamide, $50 \%$; dextran sulfate, $10 \%$; $\mathrm{NaCl}, 300 \mathrm{~mm}$; Tris, $10 \mathrm{~mm}$; EDTA, $1 \mathrm{~mm}$; yeast tRNA, $500 \mu \mathrm{g} / \mathrm{ml}$; DTT, $10 \mathrm{~mm} ; 1 \times$ Denhardt's solution; $\mathrm{pH} 8.0$ ) to a final concentration of $5 \times 10^{6} \mathrm{cpm} / \mathrm{ml}$. Hybridizations were begun by applying $100 \mu \mathrm{l}$ of hybridization solution to a $24 \mathrm{~mm} \times 60 \mathrm{~mm}$ glass coverslip and then placing the slide containing the sections over the coverslip. The edges of the coverslip were sealed with DPX, and the samples were incubated in a $58^{\circ} \mathrm{C}$ oven for $18 \mathrm{hr}$

After the $18 \mathrm{hr}$ incubation, the DPX was peeled off and the coverslips removed by agitation for $15 \mathrm{~min}$ in $4 \times$ SSC. The slides were then washed four more times ( 5 min each) with $4 \times$ SSC and subsequently transferred to a ribonuclease-containing bufter [RNase A, $20 \mu \mathrm{g} / \mathrm{ml} ; \mathrm{NaCl}, 500 \mathrm{~mm}$; Tris (pH 8.0), $10 \mathrm{~mm}$; EDTA, $1 \mathrm{~mm}$ ] and incubated at $37^{\circ} \mathrm{C}$ for $30 \mathrm{~min}$ to digest nonhybridized, single-stranded RNA. The slides were then washed and gradually desalted by incubation for 5 min each in $2 \times$ SSC, $2 \times$ SSC, $2 \times$ SSC, $1 \times$ SSC, and $0.5 \times$ SSC. All these SSC solutions contained $1 \mathrm{~mm}$ DTT to prevent oxidation of the ${ }^{35} \mathrm{~S}$-containing probes. A $30 \mathrm{~min}$ high-stringency wash was performed by incubation in $0.1 \times$ SSC containing $1 \mathrm{~mm}$ DTT at $60^{\circ} \mathrm{C}$ for $30 \mathrm{~min}$. The slides were then placed in $0.1 \times \mathrm{SSC}$ containing $1 \mathrm{~mm}$ DTT until cool $(10 \mathrm{~min})$, and dehydrated by passage through an ethanol series, 3 min each in $50 \%$, $70 \%, 95 \%, 100 \%, 100 \%$, and $100 \%$. Slides were then air dried and exposed to Amersham Hyperfilm- ${ }^{3} \mathrm{H}$ for 3-10 d.

Optimum hybridization conditions and reproducibility of the hybridizations were determined in the following preliminary experiments. (1) Hybridization as a function of probe length [full length (about 2000 bases), 1000 bases, 500 bases, 250 bases, and 125 bases; optimum signal was obtained with 500 bases]. (2) Hybridization as a function of probe concentration (input radioactivity, $2 \times 10^{5}, 5 \times 10^{5}, 1 \times 10^{6}, 2 \times 10^{6}$, $5 \times 10^{6}, 1 \times 10^{7}$, and $2 \times 10^{7} \mathrm{cpm} / \mathrm{ml}$ ); hybridization signal increased with each increase in probe concentration, but optimum signal to noise ratio was obtained using $5 \times 10^{6} \mathrm{cpm} / \mathrm{ml}$. (3) Hybridization as a function of incubation time ( $4 \mathrm{hr}, 8 \mathrm{hr}, 16 \mathrm{hr}, 24 \mathrm{hr}$, and $42 \mathrm{hr}$ ); maximum signal was obtained between 16 and $24 \mathrm{hr}$. (4) Hybridization reproducibility by comparison of signal obtained in four sets of serial sections (average variation for 10 brain areas representing the range of hybridization signals was $10.1 \%$ ). Percentage errors were comparable regardless of signal intensity. (5) Signal intensity was measured as a function of section thickness using the probe for $\beta_{2}$ to determine whether the hybridization methods used could detect differences in tissue mRNA content. The results indicated that signal intensity increased linearly for sections between $8 \mu \mathrm{m}$ and $14 \mu \mathrm{m}$ thick.

Quantitation of films. In order to relate the intensity of the film image to a relative measure of tissue radioactivity, standards containing known amounts of either ${ }^{3} \mathrm{H}$ or ${ }^{35} \mathrm{~S}$ were exposed along with tissue on each film. Tissue standards were used for ${ }^{35} \mathrm{~S}$, and both plastic standards and tissue standards were used for ${ }^{3} \mathrm{H}$. Tissue standards were prepared by mixing measured amounts of isotope with a homogenate prepared from whole brain. Actual concentrations of radioactivity were measured in weighted aliquots. The ${ }^{3} \mathrm{H}$ standards contained from 0 to $4.5 \mathrm{nCi} / \mathrm{mg}$, and the ${ }^{35} \mathrm{~S}$ standards contained from 0 to $25 \mathrm{nCi} / \mathrm{mg}$. Eight standards were used for each isotope.

The tissue standards were used to construct standard curves relating both gray level and optical density to radioactivity. These curves were then used to calculate relative radioactive content $(\mathrm{cpm} / \mathrm{mg})$ in specific brain areas. Nuclei were identified by overlaying the autoradiograms, and the thionin-stained sections and gray levels were measured using a Drexel University Image Analysis System (DUMAS) and the associated BRAIN software. Hardware used included a Dell 316 microcomputer (Dell Corp., Houston, TX), Circon 9015-H solid-state video camera (Circon Corp., Santa Barbara, CA), Chroma-pro 45 DUMAS light source
(Circle S Inc., Tempe, AZ), and a Datacube IVG-128 image processor (Datacube Inc., Peabody, MA). At least 5 and as many as 40 measurements were taken from each region for each animal, and the values thus obtained were averaged to provide the estimate of regional binding or hybridization for that animal. In addition to the quantitation of nuclei that displayed distinct signals above background, at least two brain arcas that had no detectable signal were measured to estimate nonspecific hybridization.

$t$ tests were used to compare signal intensity in the control and nicotine-treated groups within each brain nucleus.

The reproducibility of the results was determined by analyzing two sets of sections from control and drug-treated mice that had been hybridized for $\alpha_{4}$ mRNA at two different times using independently prepared cRNA probes. The results were subsequently compared using correlational analysis comparing the intensity of hybridization in the first experiment to that obtained in the second for both saline- and nicotine-treated mice. The correlation coefficients between the sets of data obtained in the two experiments were 0.95 and 0.97 for salinetreated and nicotine-treated mice, respectively. This result indicates that the measurement of the relative levels of hybridization was very reproducible. It should be noted that the absolute measurements of hybridization differed between the experiments, suggesting that the values measured provide reliable measurement of relative hybridization, rather than quantitative assessment of mRNA levels.

The limits of detection of differences in signal intensity were also estimated by exposing a series of 11 tissue standards containing ${ }^{35} \mathrm{~S}$ to film and quantitating signal intensity. The results indicated that samples differing in isotope content by $12 \%$ or less could not be differentiated, while those differing in isotope content by $19 \%$ or more could be distinguished.

Solution RNA hybridization. Measurement of $\alpha_{4}$ mRNA in solution was accomplished using cRNA probe synthesized from linearized pPHY23-1E(2) using $\alpha{ }^{32} \mathrm{P}$-UTP (specific activity, $1350 \mathrm{Ci} / \mathrm{mmol}$ when used) as the sole source of UTP. Mice that had been infused with either saline or $4.0 \mathrm{mg} / \mathrm{kg} / \mathrm{hr}$ nicotine were killed by cervical dislocation. Their brains were removed and cerebral cortex, cerebellum, and "midbrain" (thalamus and mesencephalon) were dissected and weighed. RNA was then extracted using the guanidinium thiocyanate/acid phenol method of Chomczynski and Sacchi (1987). RNA concentration was measured by absorbance at $260 \mathrm{~nm}$.

The amount of mRNA for $\alpha_{4}$ was estimated using the solution hybridization method described by Lee and Costlow (1987). Hybridization was conducted at $58^{\circ} \mathrm{C}$ in $20 \mu \mathrm{l}$ of the following buffer: formamide, $50 \%$; $\mathrm{NaCl}, 400 \mathrm{~mm}$; PIPES, $25 \mathrm{~mm}$; EDTA, $1 \mathrm{~mm}$; pH 6.8. Three or four concentrations of tissue RNA $(5-30 \mu \mathrm{g})$ were used for each brain area, and total RNA content was maintained at $100 \mu \mathrm{g}$ /incubation by varying the amount of total yeast RNA added to the mix. Radiolabeled probe $(500,000 \mathrm{cpm})$ was present in excess. At the completion of the hybridization reaction ( $16 \mathrm{hr}$ ), single-stranded RNA, including nonhybridized probe was digested by incubation with RNase A $(65 \mu \mathrm{g})$ and RNase T1 $\left(150 \mathrm{U}\right.$ ) at $37^{\circ} \mathrm{C}$ for $1 \mathrm{hr}$ in a final volume of $300 \mu \mathrm{l}$ (buffer: $\mathrm{NaCl}, 375$ mM; Tris, $75 \mathrm{~mm}$, EDTA, $5 \mathrm{~mm}$; pH 8.0). After RNase treatment, 200 $\mu \mathrm{g}$ of yeast RNA was added as carrier and TCA was added to a final concentration of $5 \%$ to precipitate nonhydrolyzed, double-stranded RNA and carrier. After a $10 \mathrm{~min}$ incubation on ice, samples were filtered onto GC50 glass fiber filters (Microfiltration Systems, Dublin, CA). Filters were washed six times with ice-cold 5\% TCA and placed in vials, 2.5 $\mathrm{ml}$ of Budget Solve (RPI, Arlington Heights, IL) was added, and radioactivity was determined using a Beckman 1800 scintillation counter (counting efficiency, 90\%). Content of $\alpha_{4}$-mRNA per microgram of RNA was estimated as the slope of the regression line relating acid-precipitable counts to amount of tissue extract.

$L^{-}{ }^{3} \mathrm{H}$-nicotine binding to tissue homogenates. The binding of $\mathrm{L}^{-}{ }^{3} \mathrm{H}-$ nicotine was measured using a modification of the method of Romano and Goldstein (1980) as described previously (Marks and Collins, 1982; Marks et al., 1986b). Mice that had been infused with either saline or $4.0 \mathrm{mg} / \mathrm{kg} / \mathrm{hr}$ nicotine were killed by cervical dislocation. Their brains were removed and cerebral cortex, cerebellum, and "midbrain" (thalamus and mesencephalon) were dissected and tissue prepared using the method of Romano and Goldstein (1980). A single concentration of radiolabeled nicotine $(3.9 \pm 0.2 \mathrm{nM})$ was used for these assays. Specific binding was determined as the difference in binding between samples containing no nonradioactive nicotine and those containing $10 \mu \mathrm{M}$ unlabeled L-nicotine. Protein was measured using the method of Lowry et al. (1951). 
Table 1. Responses of control and treated mice to acute nicotine injection

\begin{tabular}{|c|c|c|c|c|c|c|}
\hline \multirow[b]{2}{*}{$\begin{array}{l}\text { Chronic } \\
\text { treatment }\end{array}$} & \multicolumn{3}{|c|}{ Saline challenge } & \multicolumn{3}{|c|}{ Nicotine challenge $(1.0 \mathrm{mg} / \mathrm{kg})$} \\
\hline & $\begin{array}{l}\text { Y-Maze } \\
\text { crossings }\end{array}$ & $\begin{array}{l}\text { Y-Maze } \\
\text { rearings }\end{array}$ & $\begin{array}{l}\text { Body } \\
\text { temperature }\end{array}$ & $\begin{array}{l}\text { Y-Maze } \\
\text { crossings }\end{array}$ & $\begin{array}{l}\text { Y-Maze } \\
\text { rearings }\end{array}$ & $\begin{array}{l}\text { Body } \\
\text { temperature }\end{array}$ \\
\hline Saline & $61.6 \pm 4.6$ & $25.6 \pm 2.2$ & $38.4 \pm 0.1$ & $15.4 \pm 5.4$ & $2.8 \pm 1.2$ & $34.4 \pm 0.5$ \\
\hline $4.0 \mathrm{mg} / \mathrm{kg} / \mathrm{hr}$ & $57.7 \pm 4.1$ & $22.3 \pm 2.2$ & $38.2 \pm 0.1$ & $61.2 \pm 9.1$ & $9.1 \pm 2.4$ & $36.8 \pm 0.5$ \\
\hline$t$ & 0.63 & 1.03 & 1.00 & $4.33^{* * *}$ & $2.39^{*}$ & $3.38^{* * *}$ \\
\hline
\end{tabular}

Y-Maze activity (crosses and rears) and body tempcraturc werc mcasurcd in salinc- and nicotine-treated mice after acute injection of saline or $1.0 \mathrm{mg} / \mathrm{kg}$ nicotine Results shown are mean \pm SEM for 12 mice in each group. Groups were compared with $t$ tests $\left({ }^{*}, p<0.05 ; * * *, p<0.001\right)$.

\section{Results}

Tolerance. The responses of mice chronically treated with saline or nicotine $(4.0 \mathrm{mg} / \mathrm{kg} / \mathrm{hr})$ to acute challenge doses of saline or $1.0 \mathrm{mg} / \mathrm{kg}$ nicotine are summarized in Table 1 . Values for Y-maze activity (crosses and rears) and body temperature did not differ between the treatment groups after acute injection of saline. However, mice that had been chronically treated with $4.0 \mathrm{mg}$ / $\mathrm{kg} / \mathrm{hr}$ nicotine were significantly less responsive to a challenge injection of $1.0 \mathrm{mg} / \mathrm{kg}$ nicotine than were saline-treated mice, indicating that tolerance to the effects of nicotine had developed in these animals.

Solution hybridization and ligand binding in homogenates. In order to determine whether chronic nicotine infusion resulted in changes in the amount of $\mathrm{L}^{-3} \mathrm{H}$-nicotine binding and/or mRNA for $\alpha_{4}$, ligand binding and mRNA levels were measured. The mRNA for $\alpha_{4}$ was measured by RNase protection of mRNA/ cRNA hybrids in solution. The RNA was extracted from three large brain areas dissected from control and nicotine-treated mice. RNA levels measured in this manner were compared to $\mathrm{L}-{ }^{3} \mathrm{H}$-nicotine binding measured in these same areas from different animals. Results of these experiments are summarized in Table 2. Chronic drug infusion resulted in significant increases

\begin{tabular}{|c|c|c|c|}
\hline Brain region & Control & Treated & $t$ \\
\hline \multicolumn{4}{|l|}{$\begin{array}{l}\text { L-' }{ }^{3} \mathrm{H}-\text { nicotine bound } \\
\text { (fmol/mg protein) }\end{array}$} \\
\hline Cerebellum & $8.9 \pm 1.1$ & $10.0 \pm 0.8$ & 0.81 \\
\hline Cerebral cortex & $34.3 \pm 3.9$ & $58.1 \pm 4.1$ & $4.20^{* * * *}$ \\
\hline $\begin{array}{l}\text { Midbrain } \\
\text { (thalamus and } \\
\text { mesencephalon) }\end{array}$ & $90.4 \pm 7.8$ & $123.8 \pm 9.5$ & $2.71^{* *}$ \\
\hline \multicolumn{4}{|c|}{$\begin{array}{l}\text { Antisense } \alpha_{4} \text { RNA hybridized } \\
\text { (nCi }{ }^{32} \mathrm{P} / \mu \mathrm{g} \text { RNA) }\end{array}$} \\
\hline Cerebellum & $0.15 \pm 0.02$ & $0.16 \pm 0.03$ & 0.26 \\
\hline Cerebral cortex & $0.48 \pm 0.03$ & $0.46 \pm 0.02$ & 0.40 \\
\hline $\begin{array}{l}\text { Midbrain } \\
\text { (thalamus and } \\
\text { mesencephalon) }\end{array}$ & $1.07 \pm 0.04$ & $1.12 \pm 0.05$ & 0.81 \\
\hline
\end{tabular}

Brains from two separate groups of control and nicotine-treated mice were removed and three brain regions dissected. Total particulate protein was prepared from one group for measurement of ${ }^{3} \mathrm{H}$-nicotine binding, and RNA was extracted from the second group for measurement of $\alpha_{4}$-RNA by solution hybridization. Results represent mean \pm SEM for both ligand binding $(n=10)$ and solution hybridization $(n=6)$. Results from control and drug-treated mice were compared with $t$ tests $\left(* *, p<0.01 ;{ }^{* * *}, p<0.001\right)$. in the amount of $\mathrm{L}^{-3} \mathrm{H}$-nicotine binding in tissue prepared from cerebral cortex and from "midbrain" (representing thalamus and mesencephalon), but chronic treatment had no significant effect on ligand binding in cerebellum. In contrast to the increases observed in the numbers of nicotinic receptors measured with $\mathrm{L}^{-}{ }^{3} \mathrm{H}$-nicotine after chronic nicotine infusion, no changes in the amount of mRNA for $\alpha_{4}$ measured using solution hybridization were observed in any of the three brain areas (Table 2).

Autoradiographic determination of nicotine binding and nicotinic-subunit $m R N A s$. The experiment described above indicated that chronic treatment with nicotine resulted in increases in $\mathrm{L}-^{3} \mathrm{H}$-nicotine binding in two of three brain regions but had no effect on mRNA levels for $\alpha_{4}$ in any of the three dissected brain areas. The level of resolution obtained by dissection is small, and therefore, changes that may have occurred in discrete brain areas would not be observed. Subsequently, ligand binding and in situ hybridizations were performed on tissue sections and signal intensity was measured densitometrically.

Nicotine binding. Patterns of ligand binding and the effects of chronic nicotine treatment on this binding are illustrated in Figure $1 A-F$ for saline-infused mice and in Figure $1 G-L$ for nicotine-infused mice. A detailed qualitative description of the distribution of nicotine binding in mouse brain has been presented previously (Pauly et al., 1989). Nicotine binding is widely distributed throughout the brain. Many areas in the telencephalon bind nicotine, but the binding is generally of low to moderate density. In contrast, many regions in the diencephalon show high density of nicotine binding, including many thalamic nuclei, the medial habenula, the ventral lateral and dorsal lateral geniculate nuclei, and the optic tract nucleus. The interpeduncular nucleus in the mesencephalon possesses the highest density of nicotine binding sites in the brain. Several rhombencephalic nuclei demonstrate nicotine binding, but the density of binding to these sites is relatively modest. The cerebellum is virtually devoid of nicotine binding. Quantitative values for ligand binding in 93 brain regions are summarized in Table 3 .

The effects of chronic nicotine infusion on the binding of $\mathrm{L}^{3} \mathrm{H}-$ nicotine are also summarized in Table 3 . The chronic treatment resulted in substantial and widely distributed increases in ligand binding. Statistically significant increases in $\mathrm{L}^{-3} \mathrm{H}$-nicotine binding occurred in every major brain area. In the telencephalon every region in neocortex and rhinencephalon displayed significant increases in ligand binding, while in basal ganglia six of seven areas analyzed displayed significant increases. In contrast, just one of three septal areas was significantly increased after nicotine infusion. Ligand binding sites in some diencephalic areas were more resistant to change following chronic drug treatment. Only 7 of 19 thalamic areas analyzed demonstrated significantly increased binding of $\mathrm{L}^{3} \mathrm{H}$-nicotine, while 5 of $8 \mathrm{me}$ - 
tathalamic regions showed elevated binding. In contrast, two of three regions in the epithalamus and the subthalamus and all five regions in the hypothalamus were affected by nicotine infusion. Every (17 of 17) mesencephalic region, except the interpeduncular nucleus, responded to chronic nicotine treatment. (In order to determine if the lack of effect occurred because the film was overexposed, image intensity was also determined on films after a short exposure with the same result.) Most areas in the pons (four of five) and the medulla (three of four) responded to chronic nicotine treatment with increased levels of $\mathrm{L}_{-}{ }^{3} \mathrm{H}$-nicotine binding. The low density of binding sites in the cerebellum was unaffected by nicotine infusion.

The average variation (SE) in signal intensity was $6.7 \%$ of the mean for areas of control mice and $5.7 \%$ of the mean for areas of nicotine-treated mice. On average, the signal measured for $\mathrm{L}-{ }^{3} \mathrm{H}$-nicotine binding for nicotine-treated mice was $42 \%$ higher than that measured for control mice.

In situ hybridization, $\alpha_{4}$. In order to determine whether the changes in $\mathrm{L}^{-3} \mathrm{H}$-nicotine binding that occurred with chronic nicotine infusion resulted from changes in the levels of mRNA for $\alpha_{4}$, which encodes most of the receptors measured with $\mathrm{L}^{-3} \mathrm{H}-$ nicotine (Whiting and Lindstrom, 1986; Whiting et al., 1987; Lindstrom et al., 1990), in situ hybridizations were performed using sections nearly adjacent to those used to measure $\mathrm{L}^{-}{ }^{3} \mathrm{H}-$ nicotine binding. $\alpha_{4}$-mRNA was widely distributed, as illustrated in Figure $2 A-F$. Relative quantitative values for $\alpha_{4}$-signal are summarized in Table 4 . In general, the nuclei that displayed the most intense hybridization were located in the diencephalon and the mesencephalon. Regions in the diencephalon that showed strong signals for $\alpha_{4}$ include thalamic areas, the medial habenula, the lateral pretectal area, the medial geniculate, the dorsal lateral geniculate, and the diagonal band of the septum. Many areas of the septum, thalamus, and metathalamus had moderately strong hybridization, as well. The substantia nigra (pars compacta and pars lateralis) had the highest levels of message with values 1.52 -fold greater than the levels in any other brain regions. Several areas in the mesencephalon had moderate hybridization. Only a few discrete nuclei in the hindbrain displayed detectable $\alpha_{4}$ signal: the lateral dorsal pontine nucleus had a relatively strong hybridization signal; the dorsal tegmental nucleus, pontine nuclei, and the locus coeruleus had moderate signals; while the reticular brainstem region had a relatively weak signal.

In general, the intensity of hybridization in the telencephalon was weak to moderate, but a distinct rostrocaudal pattern was observed in cerebral cortex. The hybridization pattern in the cingulate cortex changed from a relatively uniform, modest signal to a distinct laminar pattern during rostrocaudal progression. The signal in the lateral cingulate was twice that in the medial cingulate. The retrosplenial cortex and the lateral orbital cortex had moderate levels of hybridization. The frontal cortex displayed four distinct bands of hybridization: the outermost layers had relatively little hybridization, while the signal in the deepest cortical layers was approximately three times greater. Two distinct layers were observed in the parietal cortex: a superficial layer that was lightly hybridized and a deeper layer with a threefold greater signal. Three layers wcrc visible in the occipital cortex: an outer layer with little or no signal, a modestly labeled middle layer, and a more strongly labeled deeper layer. Except for the subiculum and the presubiculum, which have moderate to strong signals, little hybridization was found in hippocampus. While the claustrum and the endopiriform nucleus of the basal ganglia had relatively high levels of $\alpha_{4}$ mRNA, hybridization in the caudate putamen was very low.

The values measured for $\alpha_{4}$-hybridization in mice infused with saline or $4.0 \mathrm{mg} / \mathrm{kg} / \mathrm{hr}$ nicotine are summarized in Table 4. In addition, the effect of nicotine infusion on the hybridization patterns is illustrated in Figure 2 (panels $A-F$ for control mice and panels $G-L$ for treated mice). None of the values measured in 59 brain areas in drug-treated mice differed from those measured in control animals.

The average variation (SE) in the measurements was $7.4 \%$ of the mean for areas of control micc and $7.5 \%$ of the mean for areas of nicotine-treated mice. On average, the signal measured for $\alpha_{4}$-hybridization for nicotine-treated mice was $0.1 \%$ lower than that measured for control mice.

In situ hybridizations, $\beta_{2}$. In order to determine whether the changes in $\mathrm{L}^{-} \mathrm{H}$-nicotine binding that occurred with chronic nicotine infusion resulted in changes in the levels of mRNA for $\beta_{2}$, which encodes the structural subunit for most of the receptors measured with $\mathrm{L}^{-3} \mathrm{H}$-nicotine (Whiting and Lindstrom, 1986; Whiting et al., 1987; Lindstrom et al., 1990), in situ hybridizations were performed with sections nearly adjacent to those used to measure $\mathrm{L}^{-3} \mathrm{H}$-nicotine binding and $\alpha_{4}$ hybridization. Hybridization of $\beta_{2}$ was very widely distributed, as illustrated in Figure $3 A-F$. Relative quantitative values for $\beta_{2}$ hybridization are summarized in 'Table 5 . Strong signals for $\beta_{2}$ were observed throughout the brain.

The hybridization signal did not vary markedly among the

\footnotetext{
Figure 1. Autoradiograms for $\mathrm{L}-{ }^{3} \mathrm{H}$-nicotine binding. Dark-field photographs of autoradiograms of $\mathrm{L}-{ }^{3} \mathrm{H}-$ nicotine binding are shown at six levels for both saline treatment $(A-F)$ and nicotine treatment $(G-L)$. Brighter images indicate more intense binding. Abbreviations: $A H A$, anterior hypothalamic area; $B S T$, bed $\mathrm{n}$. of stria terminalis; $C B$, cerebellum; $C G$, central gray; $C G L$, cingulate cortex; $C L$, claustrum; $C P$, caudate putamen; $C X I$, cerebral cortex, layer $1 ; D G$, dentate gyrus; $D L G$, dorsal $L G N ; D T$, dorsal tegmental $\mathrm{n}$.; $E N$, endopiriform $\mathrm{n}$.; $I C$, inferior colliculus; $L C$, locus coeruleus; $L D$, laterodorsal thalamic n.; $L R$, linear raphe; $M G$, medial geniculate; $M H$, medial habenula; $M P$, medial mammillary n., posterior part; $O T$, olfactory tubercule; $P R$, pontine reticular n.; $R E$, reuniens thalamic $\mathrm{n}$.; $R S P L$, retrosplenial cortex; $R T$, reticular thalamic n.; $S N C$, substantia nigra, compact part; $S N R$, substantia nigra, reticular part; $S U B$, subiculum; $V L$, ventrolateral thalamic n.; $V L G M$, ventral LGN, magnocellular part; $V L G P$, ventral $L G N$, parvocellular part; $V P L$, ventral posterolateral thalamic $n$.; $V P M$, ventral posteromedial thalamic n.; $Z I$, zona incerta. Note: some differences in signal intensity in these autoradiograms result from differences in the level of sectioning. See Table 3 for quantitative presentation of binding data.

Figure 2. Autoradiograms for in situ hybridization to message for $\alpha_{4}$. Dark-field photographs of autoradiograms of $\alpha_{4}$-cRNA hybridization are shown at six levels for saline treatment $(A-F)$ and nicotine treatment $(G-L)$. Brighter images indicate more intense hybridization. Abbreviations: $B S T$, bed $\mathrm{n}$. of stria terminalis; $C A I$, CAl field of hippocampus; $C B$, cerebellum; $C G L$, cingulate cortex; $C P$, caudate putamen; $D G$, dentate gyrus; $D K, \mathrm{n}$. Darkshewitsch; $D L G$, dorsal lateral geniculate; $D T$, dorsal tegmental $\mathrm{n}$; $E N$, endopiriform $\mathrm{n}$; $F R$, fasciculus retroflexus; $I C$, inferior colliculus; $I F$, interfascicular n.; $L C$, locus coeruleus; $L D$, laterodorsal thalamic n.; $M D$, mediodorsal thalamic n.; $M G$, medial geniculate; $M H$, medial habenula; $O T$, olfactory tubercle; $R S P L$, retrosplenial cortex; $S N$, substantia nigra; $S U B$, subiculum; $V L$, ventrolateral thalamic n.; $V L G$, ventrolateral geniculate $\mathrm{n}$.; $V M H$, ventromedial hypothalamus; $V P L$, ventral posterolateral thalamic $\mathrm{n}$; $V P M$, ventral posteromedial thalamic $\mathrm{n}$.; $Z I$, zona incerta. Note: some apparent differences between treatment groups may result from differences in the level of sectioning. See Table 4 for quantitative comparisons of hybridization signals.
} 


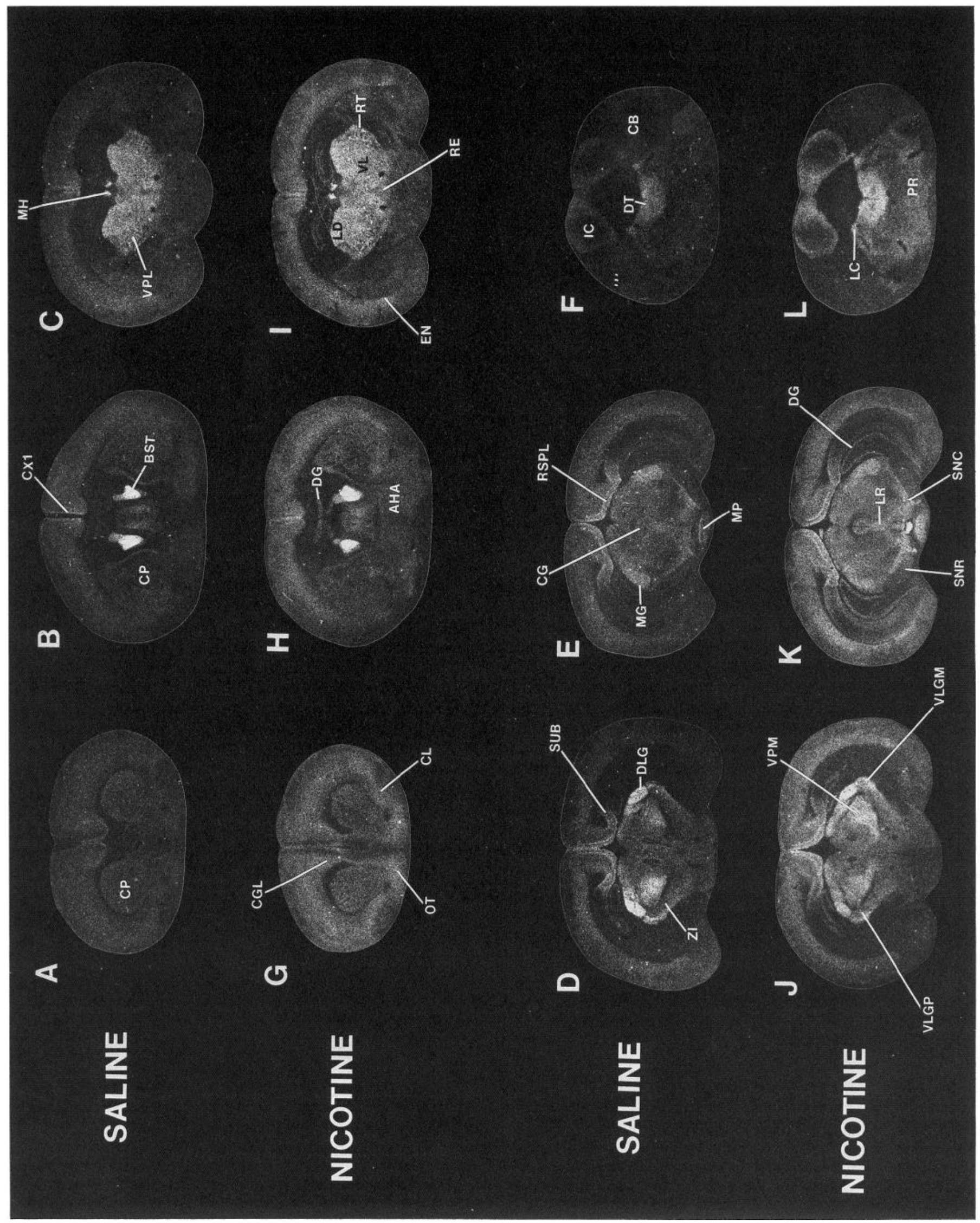



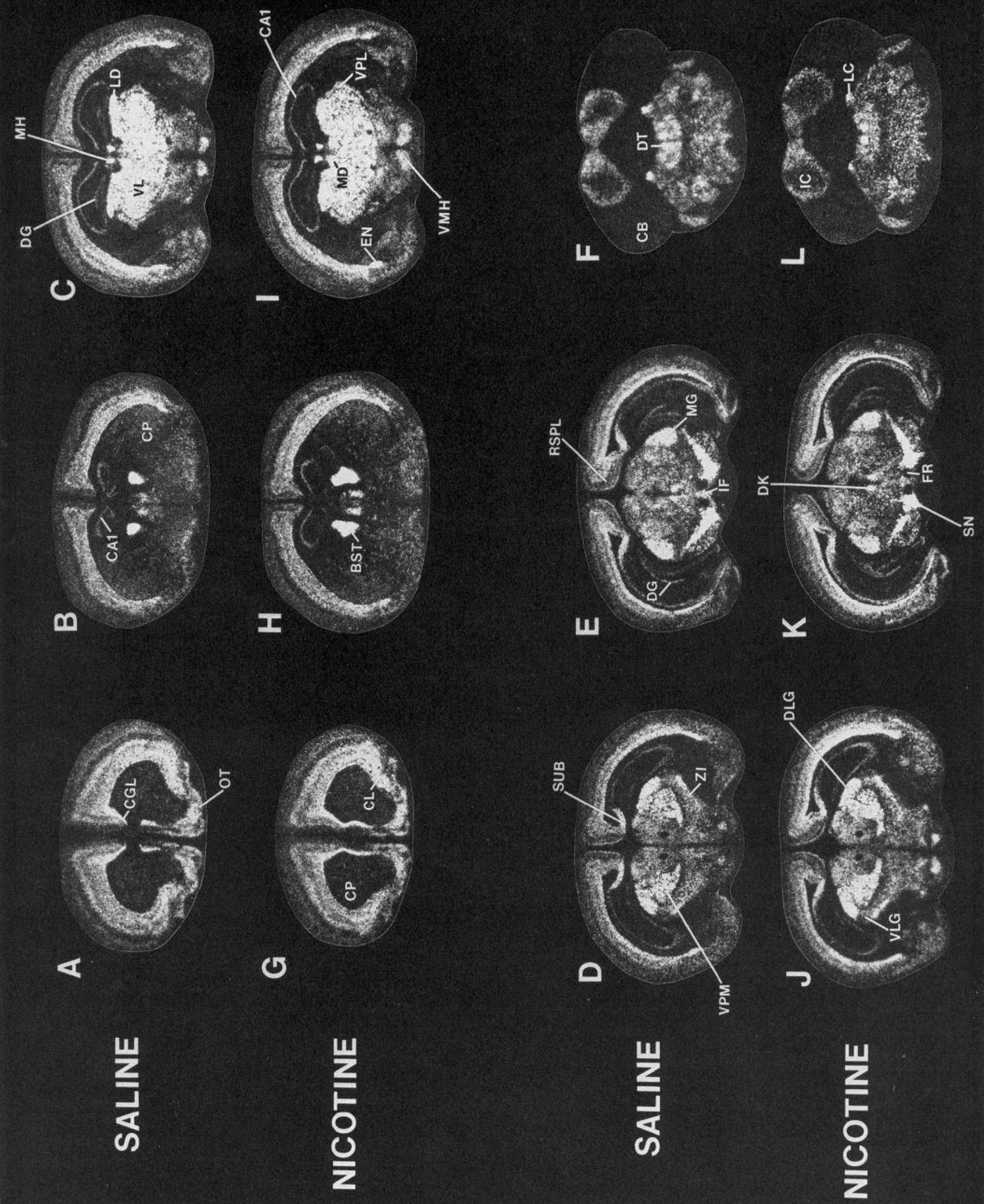
Table 3. Quantitative autoradiographic measurement of the binding of $\mathrm{L}^{-3} \mathrm{H}$-nicotine in control and nicotine-treated mice

Control Treated $\quad t$

Telencephalon

1. Neocortex

Cingulate cx (anterior)

Cingulate $\mathrm{cx}$ (posterior)

Entorhinal cx (dorsal)

Entorhinal cx (ventral)

Frontal cx (area 2)

Parietal cx (layer 1)

Parietal cx (layers 2-3)

Parietal cx (layers 4-6)

Retrosplenial cx

2. Rhinencephalon

Anterior olfactory $\mathrm{n}$.

Dentate gyrus

Presubiculum (external)

Presubiculum (internal)

Subiculum (anterior)

Subiculum (posterior)

3. Basal ganglia

Caudate putamen

Claustrum

Endopiriform n.

Nucleus acumbens

Olfactory tubercle

Stria medullaris

Substantia nigra

4. Septum

Bed n. (stria terminalis)

Fimbrial septal n.

Medial septal $\mathrm{n}$.

Diencephalon

1. Thalamus

Anterior dorsal $\mathbf{n}$.

Anterior medial $\mathrm{n}$.

Anterior ventral $\mathrm{n}$.

Centromedial $\mathrm{n}$.

Laterodorsal $\mathbf{n}$.

Mediodorsal $\mathbf{n}$.

Parafascicular $\mathrm{n}$.

Paratenial n.

Paraventricular $\mathbf{n}$.

Posterior laterodorsal n.

Reticular $\mathrm{n}$.

Reunions n.

Rhomboid $\mathbf{n}$.

Ventral posterolateral $n$.

Ventral reunions $n$.

Ventrolateral $\mathrm{n}$.

Ventromedial $\mathbf{n}$.

Ventroposterior medial $\mathbf{n}$.

2. Epithalamus and subthalamus

Medial habenula

Zona incerta (dorsal)

Zona incerta (ventral)

3. Metathalamus

Anterior pretectal n.

Dorsal LGN

$$
\begin{aligned}
& 38.48 \pm 1.5 \\
& 39.95 \pm 2.8 \\
& 23.99 \pm 3.0 \\
& 33.15 \pm 3.5 \\
& 27.63 \pm 1.2 \\
& 45.21 \pm 1.4 \\
& 22.91 \pm 1.1 \\
& 31.61 \pm 0.9 \\
& 64.60 \pm 2.4 \\
& \\
& 20.40 \pm 1.3 \\
& 17.05 \pm 1.3 \\
& 39.84 \pm 8.0 \\
& 58.12 \pm 11.1 \\
& 49.25 \pm 2.4 \\
& 67.92 \pm 2.9 \\
& 29.71 \pm 0.9 \\
& 35.35 \pm 1.3 \\
& 37.71 \pm 1.3 \\
& 24.70 \pm 1.4 \\
& 26.62 \pm 1.9 \\
& 75.67 \pm 4.8 \\
& 49.10 \pm 2.8 \\
& 112.94 \pm 4.5 \\
& 32.32 \pm 2.4 \\
& 26.45 \pm 3.0
\end{aligned}
$$

$85.65 \pm 3.8$

$102.59 \pm 3.1$

$119.39 \pm 2.5$

$61.77 \pm 3.3$

$85.23 \pm 3.0$

$76.10 \pm 2.5$

$46.55 \pm 3.4$

$69.81 \pm 3.9$

$44.03 \pm 2.3$

$68.24 \pm 5.0$

$59.27 \pm 3.0$

$60.72 \pm 2.7$

$93.35 \pm 3.9$

$54.55 \pm 1.6$

$78.27 \pm 3.9$

$76.03 \pm 2.7$

$67.75 \pm 3.9$

$74.59 \pm 3.1$

$101.26 \pm 2.9$

$32.41 \pm 3.1$

$40.98 \pm 3.1$

$36.25 \pm 3.6$

$109.54 \pm 3.3$
$49.98 \pm 3.4$

$56.87 \pm 1.4$

$46.85 \pm 5.4$

$66.96 \pm 4.8$

$41.09 \pm 4.1$

$63.38 \pm 2.1$

$34.19 \pm 1.5$

$54.61 \pm 1.4$

$90.72 \pm 2.3$

$43.13 \pm 3.9$

$36.16 \pm 1.8$

$68.84 \pm 6.3$

$92.91 \pm 5.2$

$71.90 \pm 2.3$

$97.78 \pm 2.3$

$39.59 \pm 1.8$

$59.73 \pm 2.5$

$61.70 \pm 2.7$

$41.11 \pm 2.4$

$45.07 \pm 1.9$

$69.42 \pm 3.7$

$76.15 \pm 2.6$

$111.50 \pm 4.8$

$44.14 \pm 3.7$

$33.35 \pm 1.7$

2.68 *

2.00

$98.94 \pm 5.6$

1.96

$104.95 \pm 7.0$

$121.81 \pm 2.0$

$70.46 \pm 4.3$

$97.01 \pm 6.5$

$86.66 \pm 6.5$

$63.23 \pm 2.2$

$79.87 \pm 5.6$

$63.08 \pm 3.4$

$85.93 \pm 3.1$

$64.92 \pm 1.0$

$77.05 \pm 4.9$

$103.46 \pm 3.8$

$66.94 \pm 1.4$

$91.16 \pm 3.2$

$81.73 \pm 5.0$

$68.73 \pm 2.6$

$87.93 \pm 1.7$

0.31

0.76

1.60

1.65

1.63

$3.22^{* *}$

1.47

$4.64^{* * *}$

3.01 *

1.79

$2.92^{*}$

1.86

$5.83^{* * *}$

$2.56^{*}$

1.00

0.21

$3.77^{* *}$

$105.39 \pm 5.4$

0.69

$48.06 \pm 1.2$

4.71 ****

$4.75^{* * *}$

$58.25 \pm 1.9$

$63.67 \pm 3.6$

0.67 
Table 3. Continued

\begin{tabular}{|c|c|c|c|}
\hline & Control & Treated & $t$ \\
\hline Latcral pretcctal $\mathrm{n}$. & $75.37 \pm 3.9$ & $89.47 \pm 3.5$ & $2.69 *$ \\
\hline Medial geniculate & $61.62 \pm 2.4$ & $85.98 \pm 3.3$ & $5.96^{* * *}$ \\
\hline Optic tract $n$ & $110.91 \pm 2.6$ & $105.78 \pm 3.4$ & 1.20 \\
\hline Precommissural $\mathrm{n}$. & $47.53 \pm 1.5$ & $80.56 \pm 2.5$ & $11.33^{* * *}$ \\
\hline Vlg (magnocellular) & $85.91 \pm 4.7$ & $98.14 \pm 3.4$ & 2.11 \\
\hline Vlg (parvocellular) & $48.89 \pm 3.6$ & $69.91 \pm 1.2$ & $5.30^{* * *}$ \\
\hline \multicolumn{4}{|l|}{ 4. Hypothalamus } \\
\hline Anterior hypothalamic area & $21.64 \pm 1.5$ & $36.49 \pm 1.9$ & $6.13^{* * * *}$ \\
\hline Basal region & $18.74 \pm 1.5$ & $35.91 \pm 3.7$ & $4.30^{* *}$ \\
\hline Medial mammillary $n$. & $28.01 \pm 3.8$ & $45.06 \pm 3.5$ & $3.31 * *$ \\
\hline Posterior $\mathrm{n}$. & $37.80 \pm 2.7$ & $65.88 \pm 4.4$ & $5.43^{* * *}$ \\
\hline Supramammillary $\mathrm{n}$. & $49.08 \pm 4.4$ & $74.47 \pm 3.3$ & $4.62^{* * *}$ \\
\hline \multicolumn{4}{|l|}{ Mesencephalon } \\
\hline Caudal linear raphe & $39.07 \pm 3.6$ & $62.78 \pm 6.2$ & $3.31^{* *}$ \\
\hline Central gray (dorsal) & $41.70 \pm 2.1$ & $69.21 \pm 3.2$ & $7.19^{* * *}$ \\
\hline Central gray (ventral) & $35.46 \pm 2.9$ & $59.07 \pm 3.4$ & $5.28^{* * *}$ \\
\hline Dorsal raphe & $59.41 \perp 5.4$ & $83.50 \perp 5.3$ & $3.06^{*}$ \\
\hline Ic (external) & $29.54 \pm 2.9$ & $59.74 \pm 5.4$ & $4.93^{* * *}$ \\
\hline Ic (internal) & $9.73 \pm 1.8$ & $24.12 \pm 3.3$ & $3.83^{* *}$ \\
\hline Ic (posterior) & $27.29 \pm 3.0$ & $50.52 \pm 2.8$ & $5.66^{* * *}$ \\
\hline Ipn (apical) & $174.38 \pm 6.6$ & $182.25 \pm 7.7$ & 0.80 \\
\hline Ipn (caudal) & $154.59 \pm 2.4$ & $153.91 \pm 13.0$ & 0.04 \\
\hline Ipn (central) & $159.00 \pm 6.6$ & $168.22 \pm 8.2$ & 0.88 \\
\hline Ipn (dorsomedial) & $167.76 \pm 5.2$ & $177.04 \pm 8.7$ & 0.92 \\
\hline Ipn (lateral) & $131.45 \pm 3.7$ & $140.62 \pm 4.6$ & 1.55 \\
\hline Ipn (rostral) & $146.05 \pm 1.5$ & $154.67 \pm 4.7$ & 1.52 \\
\hline Medial raphe (anterior) & $50.26 \pm 2.0$ & $68.24 \pm 3.4$ & $4.04^{* *}$ \\
\hline Medial raphe (posterior) & $43.83 \pm 4.1$ & $64.32 \pm 4.2$ & $3.49^{* *}$ \\
\hline Microcellular tegmental $\mathrm{n}$. & $41.85 \pm 4.9$ & $69.71 \pm 4.0$ & $4.04^{* *}$ \\
\hline Paranigral area & $56.28 \pm 3.5$ & $80.98 \pm 5.7$ & $3.69^{* *}$ \\
\hline Prerubral field & $23.24 \pm 2.7$ & $48.79 \pm 2.8$ & $6.57^{* * *}$ \\
\hline Rhabdoid nucleus & $83.67 \pm 0.8$ & $103.92 \pm 7.0$ & $2.61^{*}$ \\
\hline Rostral linear raphe & $41.88 \perp 2.0$ & $71.44 \perp 2.5$ & $9.23^{* * *}$ \\
\hline Sc (optic nerve) & $50.26 \pm 1.5$ & $78.03 \pm 2.9$ & $8.51^{* * *}$ \\
\hline Sc (superficial gray) & $77.26 \pm 2.0$ & $105.67 \pm 2.5$ & $8.77^{* * * *}$ \\
\hline Ventral tegmental area & $35.98 \pm 1.6$ & $51.66 \pm 2.6$ & $5.14^{* * * *}$ \\
\hline \multicolumn{4}{|l|}{ Pons } \\
\hline Dorsal tegmental $\mathrm{n}$. & $57.53 \pm 4.3$ & $76.84 \pm 4.0$ & $3.29^{* *}$ \\
\hline Laterodorsal tegmental $\mathrm{n}$. & $47.31 \pm 4.9$ & $60.28 \pm 7.3$ & $2.48^{*}$ \\
\hline Locus coeruleus & $31.72 \pm 2.3$ & $52.60 \pm 6.1$ & $3.20^{* *}$ \\
\hline Pyramidal tract & $34.09 \pm 2.5$ & $59.21 \pm 2.9$ & $6.56^{* * *}$ \\
\hline Superior olivary $n$. & $21.20 \pm 2.5$ & $28.59 \pm 4 . C$ & 1.56 \\
\hline \multicolumn{4}{|l|}{ Medulla } \\
\hline Cuneiform $\mathrm{n}$. & $40.99 \pm 9.3$ & $62.57 \pm 5.9$ & 2.05 \\
\hline Hypoglossal n. & $45.68 \pm 4.1$ & $64.24 \pm 3.9$ & $3.31^{*}$ \\
\hline Medial vestibular $n$. & $23.26 \pm 3.3$ & $32.11 \pm 2.8$ & $2.26^{*}$ \\
\hline Reticular $\mathbf{n}$ & $16.24 \pm 1.8$ & $25.86 \pm 4.2$ & $2.27^{*}$ \\
\hline \multicolumn{4}{|l|}{ Cerebellum } \\
\hline Cerebellar lobules & $1.99 \pm 0.6$ & $4.55 \pm 1.4$ & 1.68 \\
\hline
\end{tabular}

Data show ${ }^{3} \mathrm{H}$-nicotine binding in various brain regions from animals that were infused chronically with saline (control; $n=6$ ) or nicotine (treated; $4.0 \mathrm{mg} / \mathrm{kg} / \mathrm{hr}$ nicotine; $n=6$ ) for $10 \mathrm{~d}$. Quantitative autoradiography was performed as described in Materials and Methods. The groups were compared by $t$ test. Asterisks designate statistically significant differences from control binding $\left({ }^{*}, 0.05\right.$ level; $\left.* *, 0.01 ; * * *, 0.001\right)$. The following abbreviations are used: cx, cortex; vlg, ventral lateral geniculate; ic, inferior colliculus; n., nucleus; sc, superior colliculus; ipn, interpeduncular nucleus. 

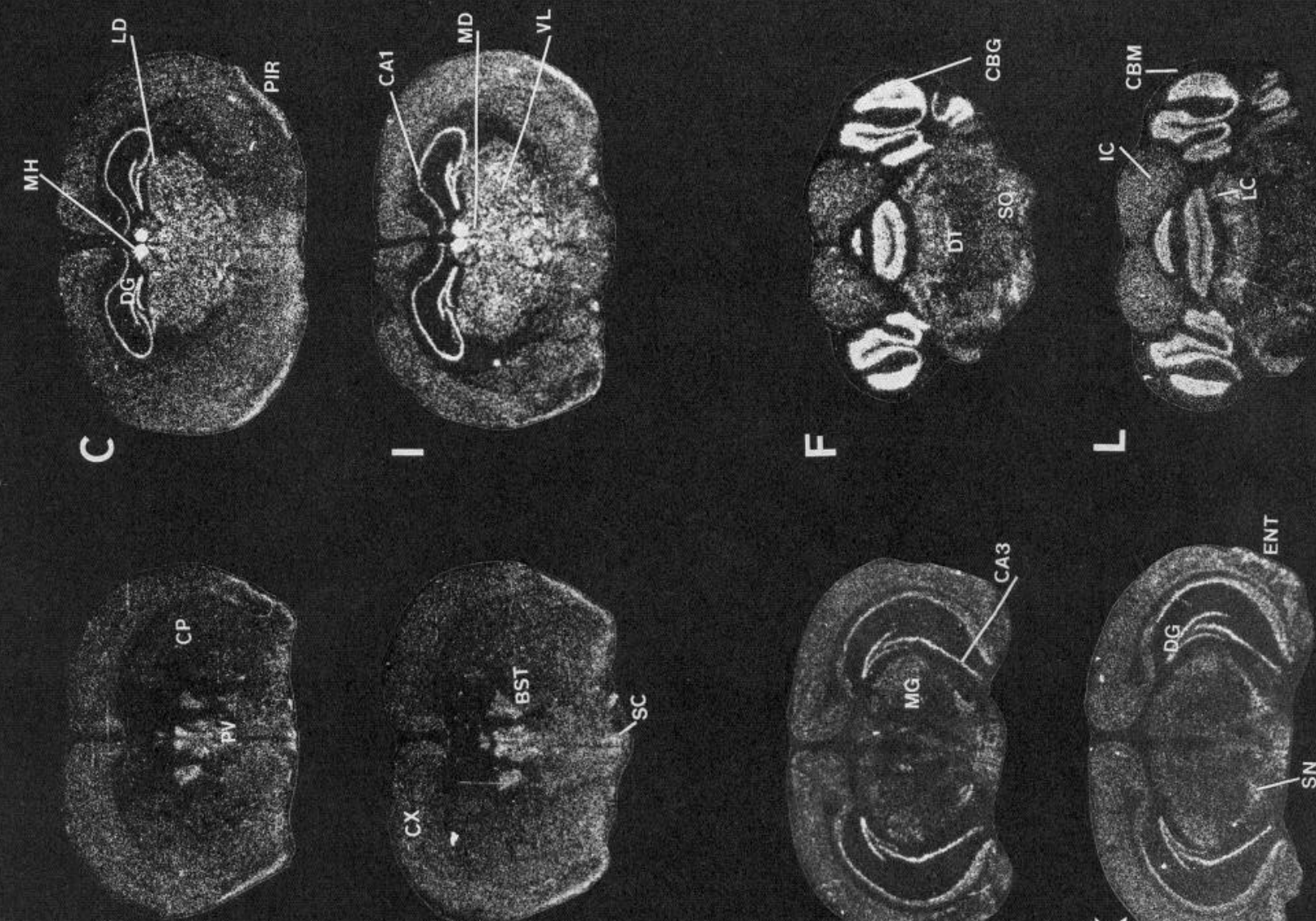

อ

I

IL
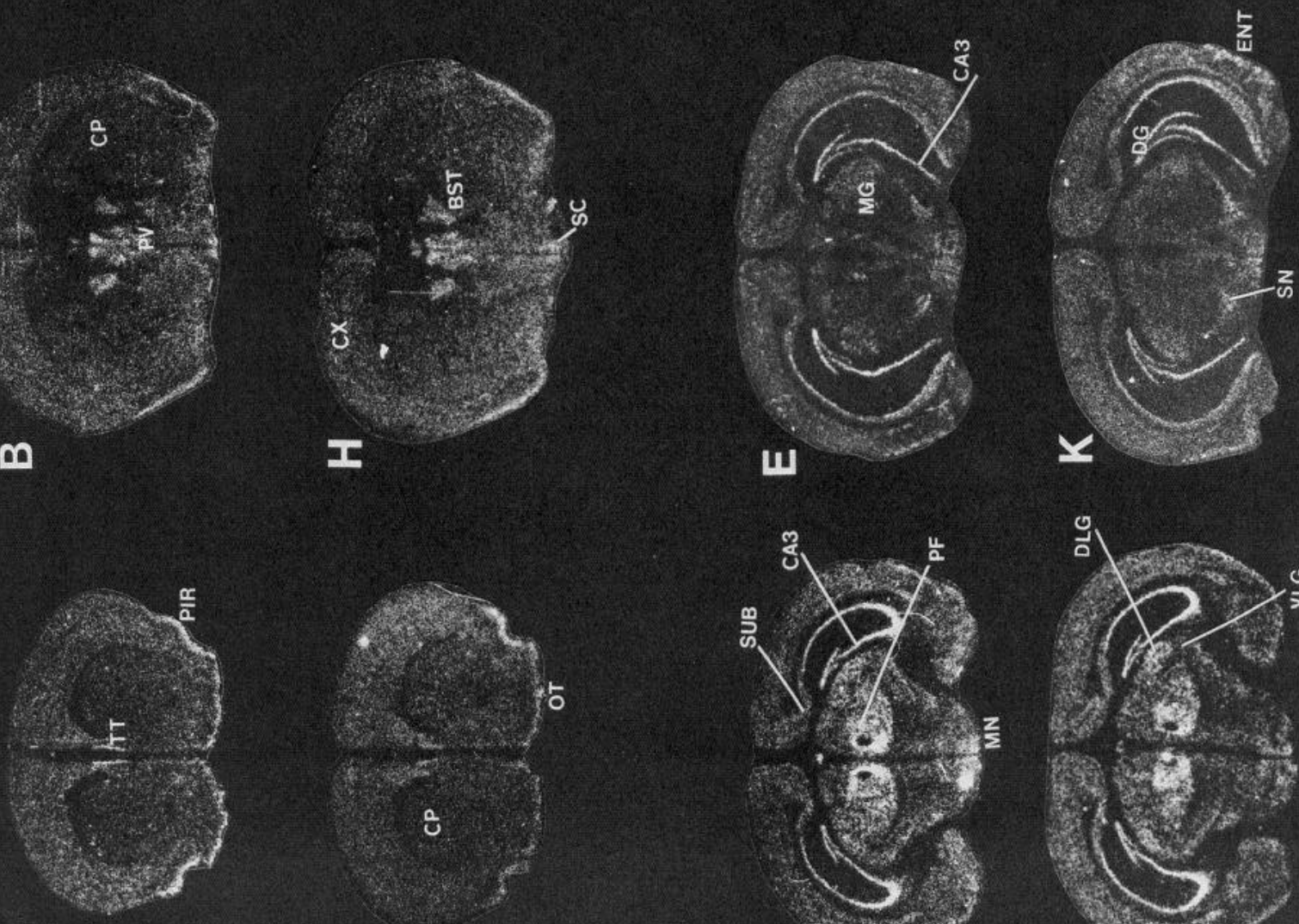

$\leftarrow$

(5)
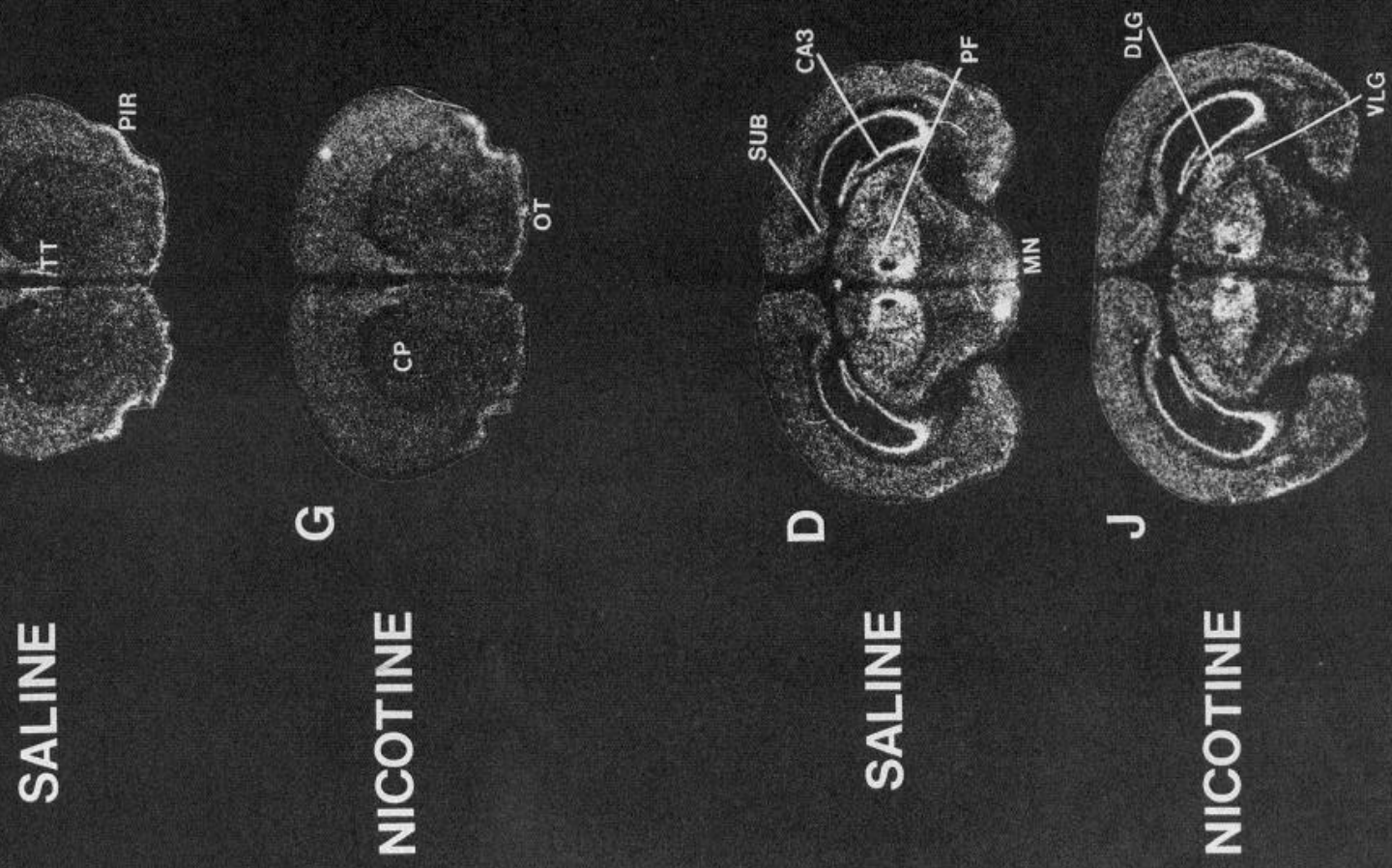

$\frac{\text { 핀 }}{\frac{1}{2}}$

$\frac{2}{2}$ 
neocortical regions of the telencephalon. No obvious differences in the intensity of hybridization were observed in layers of the frontal or the occipital cortex, but the inner layer of the parietal cortex showed more intense hybridization than did the outer layer. Many areas in the rhinencephalon had a positive hybridization signal, with the dentate gyrus, the CA2 layer of hippocampus, and the lateral olfactory tubercle being the regions mostly intensely labeled. The substantia nigra pars compacta and pars lateralis were the most highly labeled areas in the basal ganglion, and the caudate putamen was the region showing the lowest signal. The medial septum was much more intensely labeled than was the lateral septum.

As was the case with hybridization with $\alpha_{4}$, diencephalic regions were among the most intensely labeled with the $\beta_{2}$-probe. Many thalamic, metathalamic, and hypothalamic nuclei, as well as the medial and dorsal lateral geniculate, showed strong hybridization signals. The strong hypothalamic signals obtained for $\beta_{2}$ contrast with the relatively weak signals observed for $\alpha_{4}$ in this brain area. The medial habelula was the most intensely labeled nucleus in the brain.

Several mesencephalic and pontine nuclei displayed moderate to strong hybridization signals, with the signals observed in the interpeduncular nucleus, the subbrachial nucleus, the dorsal tegmental nucleus, the locus coeruleus, and the superior olivary nucleus being particularly strong. In marked contrast to the absence of hybridization of $\alpha_{4}$-probe observed in cerebellum, the hybridization intensity for the $\beta_{2}$-probe in the granule cell layer of the cerebellum was very strong.

The values measured for $\beta_{2}$-hybridization in mice infused with saline or $4.0 \mathrm{mg} / \mathrm{kg} / \mathrm{hr}$ nicotine are summarized in Table 5. In addition, the effect of nicotine infusion on the hybridization patterns is illustrated in Figure 3 (panels $A-F$ for control mice and panels $G-L$ for treated mice). The intensity of hybridization observed for $\beta_{2}$ was unaffected in 82 of 84 brain areas analyzed, but in the dorsomedial nucleus of the hypothalamus and the lateral portion of the interpeduncular nucleus, mice that had been chronically treated with nicotine had significantly lower signals than saline-treated mice.

The average variation (SE) in signal intensity within a given area was $9.3 \%$ of the mean for control mice and $9.4 \%$ of the mean for nicotine-treated mice. On average, the signal measured for $\alpha_{4}$-hybridization for nicotine-treated mice was $1.7 \%$ lower than that measured for control mice.

Summary of treatment effects on nicotine binding and $\alpha_{4^{-}}$and $\beta_{2}$-hybridizations. In order to provide a direct comparison of the magnitude of the effects of chronic nicotine treatment on $\mathrm{L}^{-}{ }^{3} \mathrm{H}$-nicotine binding and on $\alpha_{4^{-}}$and $\beta_{2}$-hybridization, frequency histograms were constructed (Fig. 4). The percentage change in signal intensity for all brain areas analyzed was calculated for each probe, and the major anatomical subdivisions for the brain regions are illustrated by different shading.

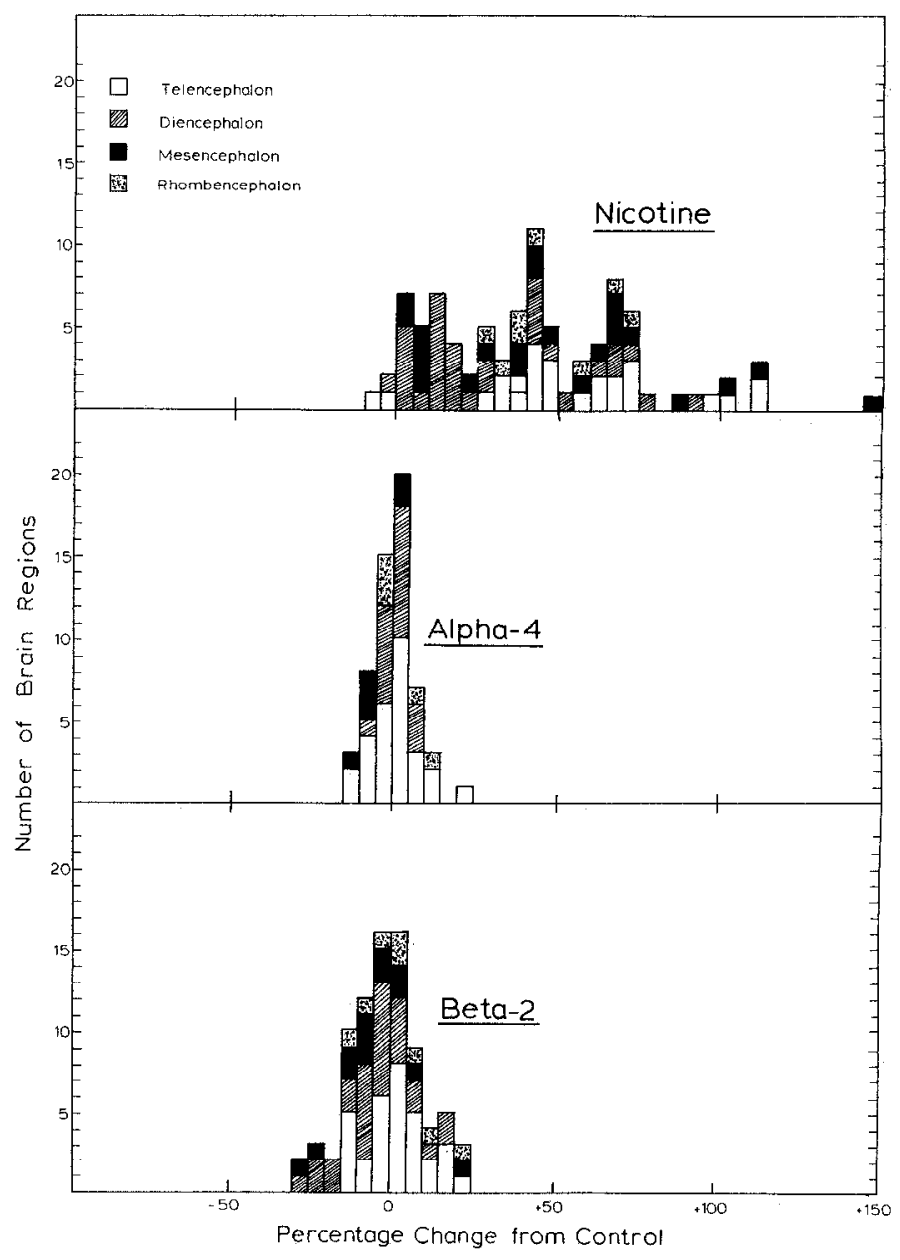

Figure 4. Relative L- ${ }^{3} \mathrm{H}$-nicotine binding and $\alpha_{4}$ and $\beta_{2}$ hybridization after nicotine treatment. Relative signal intensity after chronic nicotine infusion was calculated by dividing the mean value for ligand binding or probe hybridization measured in drug-treated mice by the mean value mcasured for saline-treated mice for each brain area that was quantitated. Results are presented as frequency histograms of the number of brain areas displaying changes from control values indicated on the abscissa. The location within a major anatomical division of each brain region quantitated is illustrated by the differential shading of the blocks.

The results presented in Figure 4 for $\mathrm{L}^{-3} \mathrm{H}$-nicotine binding demonstrate that the change in ligand binding occurring with chronic nicotine treatment varied markedly, with changes ranging from $-8 \%$ to $+147 \%$. In general, regions in the telencephalon and the rhombencephalon were more markedly affected by chronic nicotine treatment than were regions in the diencephalon. The average increase in $\mathrm{L}^{-}{ }^{3} \mathrm{H}$-nicotine binding in all brain areas was $42 \%$.

The results presented in Figure 4 for $\alpha_{4}$-hybridization illus-

\section{$\leftarrow$}

Figure 3. Autoradiograms for in situ hybridization to message for $\beta_{2}$. Dark-field photographs of autoradiograms of $\beta_{2}$ cRNA hybridization are shown at six levels for saline treatment $(A-F)$ and nicotine treatment $(G-L)$. Brighter images indicate more intense hybridization. Abbreviations: $B S T$, bed n. of stria terminalis; $C A 1$, CA1 field of hippocampus; $C A 3$, CA3 field of hippocampus; $C B G$, granule cell layer of cerebellum; $C B M$, molecular layer of cerebellum; $C P$, caudate putamen; $C X$, cerebral cortex; $D G$, dentate gyrus; $D L G$, dorsolateral geniculate; $D T$, dorsal tegmental $\mathrm{n}$.; $E N T$, entorhinal cortex; $I C$, inferior colliculus; $L C$, locus coeruleus; $L D$, laterodorsal thalamic $\mathrm{n}$.; $M D$, mediodorsal thalamic $\mathrm{n}$.; $M G$, medial geniculate; $M H$, medial habenula; $M N$, mammillary n.; $O T$, olfactory tubercle; $P F$, parafascicular thalamic n.; $P I R$, piriform cortex; $P V$, paraventricular thalamic n.; $S C$, suprachiasmatic n.; $S N$, substantia nigra; $S U B$, subiculum; $S O$, superior olivary nuclei; $V L$, ventrolateral thalamic n.; $V L G$, ventrolateral geniculate; $T T$, tenia tecta. Note: some apparent differences between treatment groups may result from differences in the level of sectioning. See Table 4 for quantitative comparisons of hybridization signals. 
Table 4. Relative quantitation of hybridization of cRNA transcribed from IHYA23-1E(2) $\left(\alpha_{4}\right)$ after chronic treatment with saline or nicotine

Control

Treated

Telencephalon

1. Neocortex

Cingulate cortex

Cingulate (lateral)

Cingulate (medial)

Frontal cortex (area 2)

Frontal cortex (deep)

Frontal cortex (mid 1)

Frontal cortex (mid 2)

Frontal cortex (outer)

Parietal cortex (inner)

Parietal cortex (outer)

Occipital cortex (inner)

Occipital cortex (mid)

Orbital cortex

Retrosplenial cortex

2. Rhinencephalon

Anterior olfactory $\mathbf{n}$.

Hippocampus

Olfactory tubercle

Presubiculum

Subiculum

Subiculum (internal)

3. Basal ganglia

Caudate putamen

Claustrum

Endopiriform

Substantia nigra (lateralis)

Substantia nigra (compacta)

4. Septum

Fimbrial $n$.

Lateral septum

Medial septum

Triangular septal $\mathbf{n}$.

Diencephalon

1. Thalamus

Centromedial $n$.

Mediodorsal $\mathbf{n}$.

Posterior $\mathbf{n}$.

Reunions n

Ventral posterolateral $\mathrm{n}$.

Ventral posteromedial $\mathbf{n}$.

Ventrolateral $n$.

2. Epithalamus and subthalamus

Medial habenula

Zona incerta

$$
\begin{aligned}
928.4 & \pm 75.1 \\
2009.7 & \pm 136.0 \\
926.6 & \pm 83.1 \\
1064.2 & \pm 108.1 \\
1322.7 & \pm 84.8 \\
1102.9 & \pm 83.5 \\
912.1 & \pm 82.2 \\
432.9 & \pm 53.5 \\
1208.1 & \pm 74.3 \\
377.5 & \pm 33.5 \\
1546.5 & \pm 70.0 \\
1072.7 & \pm 58.4 \\
1292.4 & \pm 198.3 \\
1359.1 & \pm 60.0
\end{aligned}
$$

$718.9 \pm 72.6$

Precommissural n.

4. Hypothalamus

Ventromedial $\mathrm{n}$.

Posterior area
$1470.7 \pm 206.9$

$111.3 \pm 5.8$

$672.9 \pm 53.8$

$2020.9 \pm 214.7$

$1782.3 \pm 96.3$

$860.8 \pm 57.4$

$228.5 \pm 21.5$

$1636.3 \pm 122.7$

$1922.1 \pm 109.3$

$4030.2 \pm 305.3$

$4508.3 \pm 411.7$

$1460.8 \pm 50.9$

$1668.1 \pm 242.5$

$3547.3 \pm 244.6$

$2125.6 \pm 136.2$

$2696.7 \pm 158.4$

$1188.2 \pm 88.6$

$1994.3 \pm 157.8$

$1320.1 \pm 46.1$

$2105.9 \pm 133.2$

$2098.4 \pm 126.9$

$3120.9 \pm 296.1$

$1382.7 \pm 50.2$

$1106.4 \pm 73.7$

$2618.0 \pm 161.5$

$497.1 \pm 12.3$

$2204.3 \pm 158.1$

$2268.1 \pm 122.3$

$263.2 \pm 21.9$

$1573.6 \pm 144.6$

$894.7 \pm 101.7 \quad 0.25$

$1938.8 \pm 161.8 \quad 0.34$

$850.7 \pm 60.9 \quad 0.74$

$1035.9 \pm 96.4 \quad 0.20$

$1207.4 \pm 74.4 \quad 1.02$

$1120.4 \pm 67.9 \quad 0.16$

$855.8 \pm 46.6 \quad 0.60$

$409.2 \pm 30.0 \quad 0.39$

$1225.0 \pm 62.0 \quad 0.18$

$397.0 \pm 29.1 \quad 0.44$

$1557.1 \pm 95.2 \quad 0.09$

$1044.0 \pm 58.8 \quad 0.35$

$1292.8 \pm 145.9 \quad 0.00$

$1374.3 \pm 78.7 \quad 0.15$

$1315.1 \pm 197.7 \quad 0.54$

$120.4 \pm 7.9 \quad 0.92$

$631.7 \pm 28.9 \quad 0.71$

$1949.1 \pm 124.5 \quad 0.29$

$1790.6 \pm 95.4 \quad 0.06$

$784.8 \pm 51.7 \quad 0.99$

$212.8 \pm 17.9 \quad 0.57$

$1753.8 \pm 145.9 \quad 0.60$

$1964.0 \pm 128.2 \quad 0.24$

$4512.0 \pm 348.3 \quad 1.04$

$4846.3 \pm 301.6 \quad 0.66$

$1487.5 \pm 186.3 \quad 0.12$

$820.1 \pm 77.1 \quad 0.60$

$2037.1 \pm 157.6 \quad 1.28$

$3591.3 \pm 292.8 \quad 0.11$

$2158.3 \pm 129.7$

0.17

$2720.3 \pm 136.3$

0.11

$1248.5 \pm 85.9$

0.49

$2033.0 \pm 158.5 \quad 0.17$

$1307.2 \pm 52.0 \quad 0.18$

$2168.4 \pm 136.6 \quad 0.20$

$2118.1 \pm 116.6 \quad 0.11$

$3303.1 \pm 213.0 \quad 0.50$

$1440.9 \pm 112.5 \quad 0.47$

$1040.9 \pm 55.2 \quad 0.71$

$2593.7 \pm 168.8 \quad 0.10$

$485.5 \pm 53.6 \quad 0.23$

$2264.8 \pm 148.6 \quad 0.28$

$2215.9 \pm 118.6 \quad 0.31$

$258.9 \pm 52.9 \quad 0.06$

$1520.9 \pm 130.9 \quad 0.27$

$1346.7 \pm 93.5$ 


\begin{tabular}{|c|c|c|c|}
\hline & Control & Treated & $t$ \\
\hline \multicolumn{4}{|l|}{ Mesencephalon } \\
\hline Caudal linear raphe & $1449.6 \pm 66.7$ & $1288.6 \pm 96.7$ & 1.37 \\
\hline Central gray & $1206.6 \pm 63.2$ & $1088.5 \pm 59.6$ & 1.36 \\
\hline Darkschewitsch n. & $1929.9 \pm 114.7$ & $1944.7 \pm 121.9$ & 0.97 \\
\hline Inferior colliculus & $967.9 \pm 60.5$ & $977.8 \pm 73.7$ & 0.10 \\
\hline Interpeduncular $\mathbf{n}$. & $1410.9 \pm 132.2$ & $1300.0 \pm 79.1$ & 0.77 \\
\hline Lateral central gray & $1195.5 \pm 68.3$ & $1118.8 \pm 74.6$ & 0.76 \\
\hline \multicolumn{4}{|l|}{ Pons } \\
\hline Dorsal tegmental $\mathbf{n}$. & $1830.4 \pm 85.5$ & $2048.7 \pm 157.7$ & 1.22 \\
\hline Laterodorsal tegmental $\mathbf{n}$. & $2509.5 \pm 167.4$ & $2611.9 \pm 138.0$ & 0.47 \\
\hline Locus coeruleus & $1281.1 \pm 83.8$ & $1222.4 \pm 68.3$ & 0.54 \\
\hline Pontine $\mathrm{n}$. & $1422.7 \pm 127.4$ & $1366.3 \pm 71.5$ & 0.83 \\
\hline Reticular n. & $626.3 \pm 42.3$ & $613.9 \pm 53.5$ & 0.18 \\
\hline \multicolumn{4}{|l|}{ Cerebellum } \\
\hline Cerebellum & $91.2 \pm 7.2$ & $82.9 \pm 9.2$ & 0.71 \\
\hline
\end{tabular}

Data show hybridization of ${ }^{35}$ S-cRNA for $\alpha_{4}$ in various brain regions from animals that were infused chronically with saline (control; $n=6$ ) or nicotine (treated; $4.0 \mathrm{mg} / \mathrm{kg} / \mathrm{hr}$ nicotine; $n=6$ ) for $10 \mathrm{~d}$. Quantitative autoradiography was performed as described in Materials and Methods. The groups were compared by $t$ test. No statistically significant effects of treatment were observed. Signal intensity measured in hippocampus and cerebellum do not differ from film background and represent nonspecific hybridization.

trate that chronic treatment resulted in little change in signal intensity for this probe, since the percentage changes cluster around zero. The average change observed for all regions was a $0.1 \%$ decrease, while the extreme changes observed were a $13 \%$ decrease and a $22 \%$ increase in signal intensity. No significant changes in signal intensity were found. No overall trend toward either an increase or decrease in $\alpha_{4}$ was evident.

The results presented in Figure 4 for the effect of nicotine treatment on $\beta_{2}$-hybridization are similar to those found for $\alpha_{4}$ : the percentage changes cluster around zero with an overall average decrease of $1.3 \%$ occurring after chronic nicotine treatment. The distribution observed for $\beta_{2}$ is broader than that observed for $\alpha_{4}$, reflecting, in part, the slightly larger error encountered in quantitating $\beta_{2}$-signal. Extreme changes were a $30 \%$ decrease and a $22 \%$ increase in signal intensity. Two changes were statistically significant, the $30 \%$ decrease found in the lateral portion of the interpeduncular nucleus and the $20 \%$ decrease found in the dorsomedial hypothalamus. No overall trend toward either an increase or a decrease in $\beta_{2}$-hybridization was indicated.

In situ hybridizations, other $\alpha$-subunits. Although $\alpha_{4}$ represents most of the nicotinic receptors measured with high-affinity $\mathrm{L}^{-3} \mathrm{H}$-nicotine binding, other $\alpha$-subunits exist in brain that may encode a small percentage of $\mathrm{L}^{-}{ }^{3} \mathrm{H}$-nicotine binding sites and may respond to chronic nicotine treatment in a manner different from that observed for $\alpha_{4}$. In order to determine the effects of nicotine treatment on mRNA levels for other $\alpha$-subunits, in situ hybridizations for $\alpha_{2}, \alpha_{3}$, and $\alpha_{5}$ were performed. Coronal sections illustrating the distribution for hybridization of $\alpha_{2}, \alpha_{3}$, and $\alpha_{5}$-cRNA probes at several brain levels for saline-infused mice are presented in Figure 5.

$\alpha_{2}$. The pattern of $\alpha_{2}$-hybridization is illustrated in Figure $5 \mathrm{~A}-$ $C$. The full-length cRNA probe used for hybridization tended to give relatively high background, in contrast to the probes used for the other $\alpha$-subunits. Very high-stringency wash $(0.1 \times$ $\mathrm{SSC}, 80^{\circ} \mathrm{C}, 30 \mathrm{~min}$ ) substantially reduced the background without obvious effect on the three nuclei that showed the strongest hybridization: interpeduncular nucleus and ventral and dorsal tegmental nuclei. These nuclei, in fact, were the only mouse brain areas with signals significantly exceeding background. The quantitative determination of the signals is summarized in Table 6 .

The interpeduncular nucleus and tegmental nuclei demonstrated signals substantially higher than background for both saline- and nicotine-treated mice. Chronic treatment had no significant effect on the extent of hybridization in any region.

The average variation (SE) in signal intensity for control and treated mice in the two regions displaying detectable hybridization was $11.6 \%$. On average, the signal mcasured for $\alpha_{2}-$ hybridization for nicotine-treated mice was $8 \%$ lower than that measured for control mice.

$\alpha_{3}$. The pattern for $\alpha_{3}$-hybridization is presented in Figure $5 D-F$. Hybridization that exceeded background was detected in several areas of telencephalon, diencephalon, mesencephalon, and pons. An extremely high concentration of $\alpha_{3}$-mRNA was detected in the medial habenula; the signal in the habenula was 20 -fold greater than that in the motor trigeminal nucleus, the region expressing the second highest level of mRNA (see Table 7).

Chronic nicotine treatment had no significant effect on $\alpha_{3}$ hybridization in any brain region as shown in Table 7.

The average variation (SE) in signal intensity within a given area was $9.0 \%$ of the mean for control mice and $10.9 \%$ of the mean for nicotine-treated mice. On average, the signal measured for $\alpha_{3}$-hybridization for nicotinc-treated mice was $2 \%$ lower than that measured for control mice.

$\alpha_{s}$. The pattern for $\alpha_{5}$-hybridization is illustrated in Figure $5 G-I . \alpha_{5}$-mRNA was detectable in the telencephalon (cortical layer six), the rhinencephalon (subiculum and dentate gyrus), the diencephalon (medial habenula), the mesencephalon (substantia nigra and interpeduncular nucleus), and in the pons (pyramidal tract and dorsal tegmental nucleus).

Chronic nicotine treatment had no significant effect on the signal intensity for $\alpha_{5}$ in any brain area analyzed (see Table 8).

The average variation (SE) in signal intensity within a given area was $9.9 \%$ of the mean for control mice and $11.4 \%$ of the 
Table 5. Relative quantitation of hybridization of cRNA transcribed from pSP65-49 $\left(\beta_{2}\right)$ after chronic treatment with saline or nicotine

\begin{tabular}{|c|c|c|c|}
\hline & Control & Treated & $t$ \\
\hline \multicolumn{4}{|l|}{ Telencephalon } \\
\hline \multicolumn{4}{|l|}{ 1. Neocortex } \\
\hline Entorhinal cortex & $205.2 \pm 14.9$ & $195.3 \pm 13.3$ & 0.50 \\
\hline Frontal cortex (inner) & $176.3 \pm 17.8$ & $214.5 \pm 29.8$ & 1.09 \\
\hline Frontal cortex (outer) & $153.8 \pm 8.8$ & $182.7 \pm 22.6$ & 1.08 \\
\hline Cingulate cortex & $225.6 \pm 19.1$ & $252.4 \pm 27.1$ & 0.81 \\
\hline Occipital cortex & $200.5 \pm 24.2$ & $216.2 \pm 13.2$ & 0.60 \\
\hline Parictal cortex (inner) & $227.6 \pm 17.0$ & $248.8 \pm 18.7$ & 0.82 \\
\hline Parietal cortex (outer) & $173.8 \pm 13.2$ & $194.9 \pm 16.5$ & 1.00 \\
\hline Retrosplenial cortex & $253.1 \pm 22.4$ & $263.5 \pm 16.0$ & 0.38 \\
\hline Pyriform cortex & $345.0 \pm 16.3$ & $307.6 \pm 20.4$ & 1.43 \\
\hline \multicolumn{4}{|l|}{ 2. Rhinencephalon } \\
\hline Anterior olfactory $n$. & $231.2 \pm 30.8$ & $247.4 \pm 34.9$ & 0.34 \\
\hline Dentate gyrus & $434.8 \pm 37.9$ & $429.0 \pm 32.3$ & 0.12 \\
\hline Hilus of dentate gyrus & $64.7 \pm 4.2$ & $68.7 \pm 6.4$ & 0.53 \\
\hline Hippocampus (CA1) & $308.9 \pm 23.7$ & $312.8 \pm 22.6$ & 0.12 \\
\hline Hippocampus (CA2) & $530.5 \pm 47.1$ & $550.3 \pm 48.6$ & 0.29 \\
\hline Hippocampus (CA3) & $403.1 \pm 31.8$ & $391.8 \pm 26.5$ & 0.27 \\
\hline Olfactory tubercle (medial) & $288.9 \pm 23.4$ & $309.5 \pm 22.5$ & 0.63 \\
\hline Olfactory tubercle (lateral) & $414.2 \pm 21.8$ & $381.0 \pm 21.8$ & 1.08 \\
\hline Subiculum & $253.1 \pm 22.4$ & $263.5 \pm 16.0$ & 0.38 \\
\hline \multicolumn{4}{|l|}{ 3. Basal ganglia } \\
\hline Anterior cortical amygdala & $312.4 \pm 25.7$ & $368.0 \pm 46.0$ & 0.91 \\
\hline Caudate putamen & $112.1 \pm 5.1$ & $131.1 \pm 12.1$ & 1.45 \\
\hline Diagonal band & $308.7 \pm 23.7$ & $293.6 \pm 23.1$ & 0.46 \\
\hline Medial amygdala & $350.9 \pm 26.7$ & $313.2 \pm 20.1$ & 1.10 \\
\hline Substantia nigra (compacta) & $461.8 \pm 46.7$ & $411.2 \pm 24.6$ & 0.96 \\
\hline Substantia nigra (lateralis) & $394.8 \pm 41.5$ & $379.1 \pm 25.0$ & 0.38 \\
\hline \multicolumn{4}{|l|}{ 4. Septum } \\
\hline Bed n. (stria terminalis) & $234.7 \pm 19.6$ & $244.5 \pm 25.6$ & 0.30 \\
\hline Lateral & $196.0 \pm 17.4$ & $191.4 \pm 22.0$ & 0.05 \\
\hline Medial & $502.7 \pm 57.8$ & $590.0 \pm 77.8$ & 0.91 \\
\hline \multicolumn{4}{|l|}{ Diencepahlon } \\
\hline \multicolumn{4}{|l|}{ 1. Thalamus } \\
\hline Centromedial $\mathrm{n}$. & $475.4 \pm 48.0$ & $486.3 \pm 60.4$ & 0.12 \\
\hline Laterodorsal $\mathbf{n}$. & $355.1 \pm 21.5$ & $393.0 \pm 37.4$ & 0.88 \\
\hline Lateroposterior $\mathbf{n}$. & $336.7 \pm 31.8$ & $295.0 \pm 25.9$ & 1.02 \\
\hline Mediodorsal n. (lateral) & $379.8 \pm 25.2$ & $352.8 \pm 27.4$ & 0.73 \\
\hline Mediodorsal n. (central) & $572.1 \pm 56.6$ & $556.4 \pm 62.8$ & 0.18 \\
\hline Optic tract $\mathrm{n}$ & $254.6 \pm 25.8$ & $255.7 \pm 33.7$ & 0.03 \\
\hline Parafascicular n. & $555.1 \pm 65.6$ & $538.4 \pm 34.5$ & 0.23 \\
\hline Posterior $\mathbf{n}$. & $175.3 \pm 15.3$ & $206.7 \pm 19.4$ & 1.22 \\
\hline Reunions n. & $502.4 \pm 50.6$ & $590.8 \pm 69.2$ & 1.03 \\
\hline Subthalamic $n$. & $356.2 \pm 27.7$ & $343.5 \pm 6.6$ & 0.76 \\
\hline Ventromedial $\mathbf{n}$. & $334.0 \pm 21.7$ & $339.8 \pm 27.3$ & 0.16 \\
\hline Ventroposterior $\mathbf{n}$. & $372.2 \pm 27.2$ & $366.2 \pm 28.3$ & 0.15 \\
\hline Ventroposterolateral n. & $234.6 \pm 24.0$ & $250.2 \pm 23.9$ & 0.46 \\
\hline \multicolumn{4}{|l|}{ 2. Epithalamus and subthalamus } \\
\hline Medial habenula (caudal) & $1037.8 \pm 92.9$ & $1117.3 \pm 109.3$ & 0.29 \\
\hline Medial habenula (rostral) & $634.0 \pm 78.8$ & $583.3 \pm 59.5$ & 0.52 \\
\hline Zona incerta & $278.6 \pm 18.5$ & $264.7 \pm 19.0$ & 0.53 \\
\hline \multicolumn{4}{|l|}{ 3. Metathalamus } \\
\hline Dorsolateral geniculate & $426.0 \pm 32.7$ & $383.7 \pm 29.6$ & 0.96 \\
\hline Medial geniculate & $364.7 \pm 27.0$ & $359.3 \pm 23.5$ & 0.15 \\
\hline Ventrolateral geniculate & $225.0 \pm 20.9$ & $202.2 \pm 17.3$ & 0.84 \\
\hline
\end{tabular}




\section{Table 5. Continued}

\begin{tabular}{|c|c|c|c|}
\hline & Control & Treated & $t$ \\
\hline \multicolumn{4}{|l|}{ 4. Hypothalamus } \\
\hline Dorsomedial $\mathrm{n}$. & $407.2 \pm 25.6$ & $325.5 \pm 25.9$ & $2.24^{*}$ \\
\hline Mammillary $\mathrm{n}$. & $405.4 \pm 48.9$ & $331.8 \pm 20.0$ & 1.39 \\
\hline Periventricular area & $351.4 \pm 26.3$ & $338.7 \pm 25.6$ & 0.34 \\
\hline Posterior $\mathrm{n}$. & $255.8 \pm 23.1$ & $221.7 \pm 22.7$ & 1.05 \\
\hline Premammillary n. (dorsal) & $518.3 \pm 69.2$ & $375.3 \pm 37.1$ & 1.91 \\
\hline Premammillary n. (ventral) & $539.5 \pm 54.4$ & $415.8 \pm 40.6$ & 1.82 \\
\hline Suprachiasmatic $n$. & $487.1 \pm 35.8$ & $462.5 \pm 57.9$ & 0.39 \\
\hline Supramammillary $\mathbf{n}$. & $335.5 \pm 74.3$ & $305.4 \pm 26.9$ & 0.42 \\
\hline Ventromedial $\mathrm{n}$. & $373.4 \pm 10.9$ & $380.4 \pm 31.6$ & 0.21 \\
\hline \multicolumn{4}{|l|}{ Mesencephalon } \\
\hline Anterior pretectal area & $309.2 \pm 34.3$ & $282.6 \pm 49.4$ & 0.46 \\
\hline Central gray (dorsal) & $230.1 \pm 16.9$ & $231.0 \pm 18.1$ & 0.03 \\
\hline Central gray (ventral) & $313.7 \pm 24.1$ & $308.1 \pm 28.5$ & 0.15 \\
\hline Darkschewitsch n. & $309.8 \pm 38.3$ & $281.2 \pm 27.4$ & 0.61 \\
\hline Inferior colliculus & $264.3 \pm 20.4$ & $282.0 \pm 25.5$ & 0.54 \\
\hline Interpeduncular n. (medial) & $505.5 \pm 56.9$ & $443.8 \pm 63.5$ & 0.72 \\
\hline Interpeduncular n. (lateral) & $440.2 \pm 42.4$ & $307.6 \pm 29.7$ & $2.56^{*}$ \\
\hline Linear raphe & $335.9 \pm 20.7$ & $284.4 \pm 18.7$ & 1.85 \\
\hline Subbrachial n. & $416.5 \pm 16.6$ & $326.6 \pm 45.7$ & 1.61 \\
\hline Superior colliculus & $293.7 \pm 14.7$ & $290.3 \pm 25.7$ & 0.12 \\
\hline Ventral tegmental area & $255.1 \pm 30.0$ & $260.4 \pm 42.1$ & 0.10 \\
\hline \multicolumn{4}{|l|}{ Pons } \\
\hline Dorsal tegmental $\mathrm{n}$. & $457.1 \pm 53.1$ & $435.5 \pm 39.8$ & 0.33 \\
\hline Laterodorsal tegmental $\mathrm{n}$. & $293.5 \pm 17.0$ & $327.6 \pm 26.5$ & 1.03 \\
\hline Locus coeruleus & $531.6 \pm 69.6$ & $538.2 \pm 51.7$ & 0.08 \\
\hline Preolivary n. (caudal) & $254.8 \pm 41.9$ & $232.0 \pm 21.2$ & 0.54 \\
\hline Preolivary n. (rostral) & $297.2 \pm 23.5$ & $358.9 \pm 29.6$ & 1.01 \\
\hline Pontine $\mathrm{n}$. & $344.1 \pm 39.6$ & $305.9 \pm 40.3$ & 0.68 \\
\hline Superior olivary $n$. & $486.6 \pm 110.0$ & $532.2 \pm 88.1$ & 0.32 \\
\hline Trigeminal $\mathbf{n}$. & $242.3 \pm 19.7$ & $245.9 \pm 19.7$ & 0.13 \\
\hline \multicolumn{4}{|l|}{ Cerebellum } \\
\hline Granule cell layer & $673.1 \pm 50.9$ & $626.7 \pm 71.2$ & 0.53 \\
\hline Molecular layer & $86.2 \pm 5.8$ & $86.7 \pm 5.4$ & 0.06 \\
\hline \multicolumn{4}{|l|}{ Miscellaneous } \\
\hline Anterior commissure & $73.7 \pm 10.9$ & $86.8 \pm 14.7$ & 0.68 \\
\hline Corpus callosum (forceps mn) & $88.1 \pm 14.2$ & $88.3 \pm 10.1$ & 0.01 \\
\hline Infralimbic cortex & $325.0 \pm 21.1$ & $324.5 \pm 32.2$ & 0.01 \\
\hline Choroid plexus & $681.1 \pm 73.3$ & $583.2 \pm 67.3$ & 0.98 \\
\hline Corticospinal tract & $305.9 \pm 33.6$ & $271.0 \pm 33.1$ & 0.74 \\
\hline
\end{tabular}

Data show hybridization of ${ }^{35} \mathrm{~S}$-cRNA for $\beta_{2}$ in various brain regions from animals that were infused chronically with saline (control; $n=6$ ) or nicotine (treated; $4.0 \mathrm{mg} / \mathrm{kg} / \mathrm{hr}$ nicotine; $n=6$ ) for $10 \mathrm{~d}$. Quantitative autoradiography was performed as described in Materials and Methods. The groups were compared by $t$ test. Statistically significant effects of treatment were observed in two brain areas marked with asterisks. Signal intensity measured in the hilus of the dentate gyrus, anterior commissure, corpus callosum, and light areas of cerebellum does not differ from film background and represents nonspecific hybridization.

mean for nicotine-treated mice. On average, the signal measured for $\alpha_{5}$-hybridization for nicotine-treated mice was $12.5 \%$ higher than that measured for control mice.

\section{Discussion}

It has been previously demonstrated that chronic exposure to nicotine results in an increase in the numbers of putative nicotinic receptors measured by the binding of radiolabeled nicotinic agonists such as nicotine or ACh in mouse (Marks et al., 1983, 1985, 1986a), rat (Schwartz and Kellar, 1983), and human (Benwell et al., 1988) brain. The results of the present study confirm these observations. The results also indicate that the increase in $\mathrm{L}-{ }^{3} \mathrm{H}$-nicotine binding is not universal: many regions in the diencephalon, as well as the interpeduncular nucleus, were unaffected by chronic treatment. The differential response of nicotinic sites to chronic nicotine treatment in different brain areas is consistent with the observations made in rat brain (Kellar et al., 1989) and mouse brain (Pauly et al., 1991). The mechanism by which the increase in receptor number occurs and the reasons for the differential response in different brain areas are, as yet, unknown. One possible explanation is that the increase in receptors is regulated by an increase in transcription or stabilization of the mRNA, resulting in an elevation of the amount of RNA encoding the receptor subunits. 


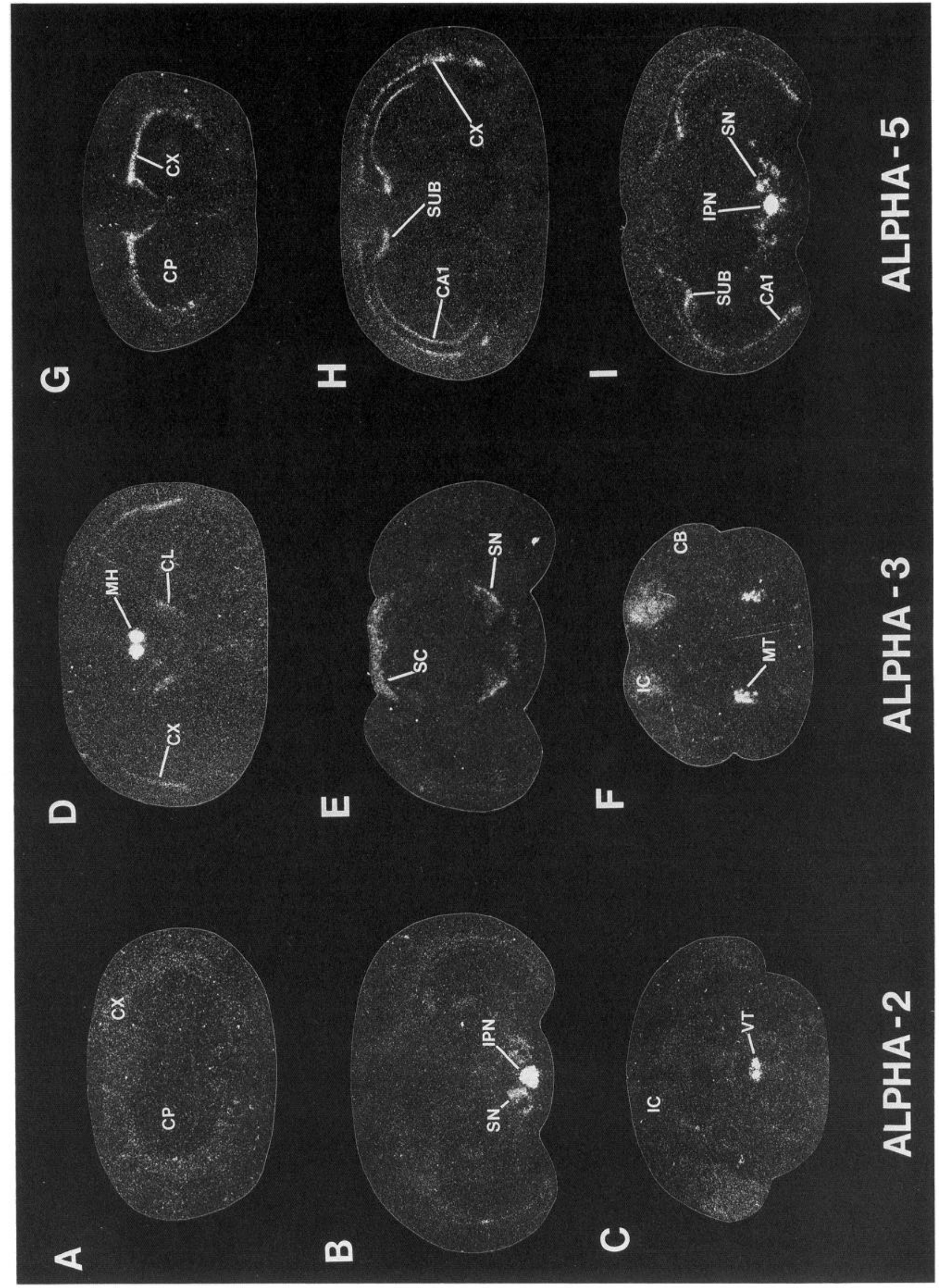




\begin{tabular}{|c|c|c|c|}
\hline & Control & Treated & $t$ \\
\hline \multicolumn{4}{|l|}{ Telencephalon } \\
\hline \multicolumn{4}{|l|}{ 1. Rhinencephalon } \\
\hline Hippocampus & $98.9 \pm 8.1$ & $115.5 \pm 9.5$ & 1.33 \\
\hline \multicolumn{4}{|l|}{ 2. Basal ganglia } \\
\hline Caudate putamen & $98.5 \pm 11.0$ & $113.1 \pm 9.8$ & 0.99 \\
\hline \multicolumn{4}{|l|}{ Mesencephalon } \\
\hline Interpeduncular $\mathrm{n}$. & $1511.1 \pm 284.0$ & $1440.4 \pm 141.9$ & 0.22 \\
\hline \multicolumn{4}{|l|}{ Pons } \\
\hline $\begin{array}{l}\text { Tegmental n. } \\
\text { (dorsal and ventral) }\end{array}$ & $1681.4 \pm 233.8$ & $1495.2 \pm 61.4$ & 0.77 \\
\hline
\end{tabular}

Data show hybridization of ${ }^{35} \mathrm{~S}$-cRNA for $\alpha_{2}$ in various brain regions from animals that were infused chronically with saline (control; $n=6$ ) or nicotine (treated; $4.0 \mathrm{mg} / \mathrm{kg} / \mathrm{hr}$ nicotine; $n=6$ ) for $10 \mathrm{~d}$. Quantitative autoradiography was performed as described in Materials and Methods. The groups were compared by $t$ test. No significant effects of treatment were observed. Image intensity measured in hippocampus and caudate putamen represents background hybridization and does not differ from film background.

The goal of the present study was to determine whether chronic nicotine treatment affected the level of RNA encoding several subunits of nicotinic cholinergic receptors in mouse brain. The time of treatment and the dose of nicotine used were chosen to result in maximal increases in $\mathrm{L}^{3} \mathrm{H}$-nicotine binding sites in mouse brain; that is, the receptor levels were at steady state. While most of the receptors that bind nicotine with high affinity in adult rodent brain appear to be composed of a single subtype $\left(\alpha_{4}, \beta_{2}\right)$ (Whiting and Lindstrom, 1986; Whiting et al., 1987; Lindstrom et al., 1990), other subunits may contribute minor components of nicotine binding. Therefore, in addition to $\alpha_{4}$ and $\beta_{2}$, other $\alpha$-subunits known at the time this study was undertaken $\left(\alpha_{2}, \alpha_{3}\right.$, and $\left.\alpha_{5}\right)$ were measured as well. The results obtained in the present study strongly suggest that chronic nicotine infusion of mice does not result in a steady-state increase (or decrease) in the amount of RNA coding for $\alpha_{4}$-subunit, which is likely to be the major agonist-binding subunit responsible for high-affinity nicotine binding, or in a change in the levels of RNA for three other, less widely distributed, $\alpha$-subunits. Similarly, chronic nicotine treatment had little effect on the amount of RNA encoding the $\beta_{2}$-subunit, which is the likely major structural subunit in the nicotinic receptor complex measured with $\mathrm{L}^{3} \mathrm{H}$-nicotine binding. The premise that high-affinity $\mathrm{L}-{ }^{3} \mathrm{H}-$ nicotine binding measures nicotinic receptors composed of $\alpha_{4}$ - and $\beta_{2}$-subunits is also supported by studies in which antibodies prepared to the cytoplasmic domain of both the $\alpha_{4}$ - and $\beta_{2}$ subunits precipitate the binding sites both before and after chronic nicotine treatment in rats (Flores et al., 1992).

Complete mapping of nicotinic receptor subunit protein and comparison to mRNA encoding the protein subunits have not yet been accomplished. Consequently, the correspondence between mRNA levels in a specific brain area and the protein encoded by that mRNA in the same or a different brain area remains unknown. The present study made no attempt to establish such a correspondence. In order to overcome partially the limitations imposed by absence of information on the relationship between mRNA and protein, the signal intensity for $\mathrm{L}^{-3} \mathrm{H}$-nicotine binding and nicotinic subunit mRNA was measured in as many brain areas as possible in order to determine if chronic nicotine treatment affected any or all of these measures. The results presented in Tables 3-5 and summarized in Figure 4 indicate that chronic nicotine treatment resulted in a general increase in the amount of $\mathrm{L}^{-3} \mathrm{H}$-nicotine binding, without effect on the levels of mRNA encoding either $\alpha_{4}$ - or $\beta_{2}$-subunits. Therefore, even though a definitive assignment of a relationship between mRNA and protein within specific brain nuclei cannot be made, the observation that mRNA levels were unaffected by chronic drug treatment strongly suggests that, if the $\mathrm{L}^{-3} \mathrm{H}$-nicotine binding measures the amount of nicotinic receptor composed of $\alpha_{4}$ - and $\beta_{2}$-subunits, the increase in nicotinic receptors measured by high-affinity nicotine binding is not controlled by a simple increase in transcription of mRNA or lower rate of degradation of the mRNA for the nicotinic $\mathrm{ACh}$ receptor subunits measured in this study.

Methods to quantitate mRNA in neural tissue by in situ hybridization have not been widely used. The several control experiments described in the present article suggest that in situ hybridization performed under controlled conditions using a single preparation of cRNA probe within an experiment and analyzed using quantitative video image analysis provides at least a relative measurement of $m R N A$ levels. In addition, the results obtained by quantitation of the in situ hybridizations were consistent with the results obtained independently using solution hybridization methods.

Examination of the relative variability (as estimated by the average SE values of the measurements within each brain area) indicates that the reliability of the quantitation of mRNA levels was comparable to the reliability of the quantitation of $\mathrm{L}^{-3} \mathrm{H}$ nicotine binding. The reliability of the measurements sets the limits for detection of statistically significant changes from con-

\footnotetext{
Figure 5. Autoradiograms for in situ hybridization to message for $\alpha_{2}, \alpha_{3}$, and $\alpha_{5}$. Dark-field photographs of autoradiograms for hybridization of cRNA for $\alpha_{2}(A-C), \alpha_{3}(D-F)$, and $\alpha_{5}(G-I)$ are shown at three different levels for each message in saline-treated mice. Brighter images indicate more intense hybridization. Abbreviations: $C A 1, \mathrm{CA} 1$ region of hippocampus; $C B$, cerebellum; $C L$, centrolateral thalamic n.; $C P$, caudate putamen; $C X$, cerebral cortex; $I C$, inferior colliculus; $I P N$, interpeduncular $\mathrm{n}$; $M H$, medial habenula; $M T$, motor trigeminal $\mathrm{n}$; $S C$, superior colliculus; $S N$, substantia nigra; $S U B$, subiculum; $V T$, ventral tegmental $\mathrm{n}$.
} 
Table 7. Relative quantitative hybridization of cRNA transcribed from pPCA48E(4) $\left(\alpha_{3}\right)$ to brain regions from control and nicotine-treated mice

\begin{tabular}{|c|c|c|c|}
\hline & Control & Treated & $t$ \\
\hline \multicolumn{4}{|l|}{ Tclencephalon } \\
\hline \multicolumn{4}{|l|}{ 1. Neocortex } \\
\hline Cerebral cortex (layer IV) & $201.6 \pm 8.5$ & $191.1 \pm 6.7$ & 0.98 \\
\hline \multicolumn{4}{|l|}{ 2. Rhinencephalon } \\
\hline Hippocampus & $71.0 \pm 9.5$ & $72.2 \pm 8.2$ & 0.10 \\
\hline \multicolumn{4}{|l|}{ 3. Basal ganglia } \\
\hline Bed $\mathbf{n}$. of stria terminalis & $156.2 \pm 15.6$ & $183.1 \pm 47.7$ & 0.66 \\
\hline Caudate putamen & $75.8 \pm 7.6$ & $75.5 \pm 7.2$ & 0.99 \\
\hline Substantia nigra & $466.6 \pm 33.5$ & $425.1 \pm 45.3$ & 0.74 \\
\hline \multicolumn{4}{|l|}{ Diencephalon } \\
\hline \multicolumn{4}{|l|}{ 1. Epithalamus and subthalamus } \\
\hline Medial habenula & $14,711.0 \pm 1456.7$ & $12,328.6 \pm 514.6$ & 1.54 \\
\hline Stria medularis & $150.2 \pm 7.4$ & $175.5 \pm 13.0$ & 1.51 \\
\hline \multicolumn{4}{|l|}{ 2. Metathalamus } \\
\hline Medial geniculate $\mathbf{n}$. & $421.0 \pm 47.8$ & $367.1 \pm 32.7$ & 0.96 \\
\hline \multicolumn{4}{|l|}{ 3. Hypothalamus } \\
\hline Anterior hypothalamic area & $198.3 \pm 16.1$ & $188.1 \pm 11.3$ & 0.49 \\
\hline Hypothalamus (remaining) & $136.3 \pm 18.6$ & $130.0 \pm 22.0$ & 0.22 \\
\hline Suprachiasmatic $\mathrm{n}$. & $247.7 \pm 29.2$ & $269.4 \pm 37.7$ & 0.47 \\
\hline Ventromedial hypothalamus & $396.9 \pm 16.8$ & $297.9 \pm 48.5$ & 0.30 \\
\hline \multicolumn{4}{|l|}{ Mesencephalon } \\
\hline Inferior colliculus & $475.5 \pm 56.4$ & $476.6 \pm 45.8$ & 0.01 \\
\hline Intercollicular area & $257.0 \pm 18.5$ & $256.4 \pm 19.9$ & 0.01 \\
\hline Interpeduncular n. & $397.9 \pm 49.6$ & $434.3 \pm 60.0$ & 0.81 \\
\hline Superior colliculus & $516.4 \pm 10.6$ & $480.2 \pm 32.8$ & 0.56 \\
\hline Ventral tegmental area & $80.3 \pm 10.7$ & $77.7 \pm 12.0$ & 0.16 \\
\hline \multicolumn{4}{|l|}{ Pons } \\
\hline Medial vestibular $\mathbf{n}$. & $321.9 \pm 58.8$ & $302.8 \pm 34.5$ & 0.23 \\
\hline Motor trigeminal $\mathrm{n}$. & $794.7 \pm 71.2$ & $827.4 \pm 100.6$ & 1.03 \\
\hline
\end{tabular}

Data show hybridization of ${ }^{35} \mathrm{~S}$-cRNA for $\alpha_{3}$ in various brain regions from animals that were infused chronically with saline (control; $n=6$ ) or nicotine (treated; $4.0 \mathrm{mg} / \mathrm{kg} / \mathrm{hr}$ nicotine; $n=6$ ) for $10 \mathrm{~d}$. Quantitative autoradiography was performed as described in Materials and Methods. The groups were compared by $t$ test. No significant effects of treatment were observed. Hybridization measured in hippocampus, caudate putamen, and ventral tegmental area represents nonspecific hybridization and does not differ from film background.

trol values after chronic nicotine treatment. The limits can be estimated from the SE values of the two groups, the value of $t$ in the $t$ test, and the degrees of freedom determined by the group sizes. Using these calculations, average differences between control and nicotine-treated groups of about $20 \%$ for $\mathrm{L}^{-3} \mathrm{H}$-nicotine binding, $24 \%$ for $\alpha_{4}$-hybridization, and $31 \%$ for $\beta_{2}$-hybridization are required to achieve statistical significance. The average changes observed experimentally for each measure were $+42 \%$, $-0.1 \%$, and $-1.7 \%$, respectively. The comparison of relative errors of measurement and changes in signal intensity after chronic treatment strongly suggest that failure to observe changes in intensity of hybridization did not arise from fundamental differences in the reliability of measurement for the various probes.

In the absence of an effect of chronic nicotine treatment on RNA levels encoding four $\alpha$-subunits or the $\beta_{2}$-subunit, regulation of steady-state changes in receptor levels (measured as binding sites) seems likely to result from changes in posttranscriptional processing, at least for the subunits measured. Among possible explanations for increased receptor levels in the absence of increased levels of message are increases in translational efficiency, decreases in protein degradation rates, increased in- corporation of receptors from premade pools, or activation of previously inactive receptors.

Studies on the dopamine receptor system suggest that chronic drug treatment may not affect mRNA encoding various subtypes of dopamine receptors. Treatment of rats with dopamine antagonists, such as haloperidol, resulted in increases in dopaminergic receptors as measured by increases in the numbers of binding sites, but had no significant effect on mRNA encoding for these receptor proteins (van Tol et al., 1990; Xu et al., 1992). However, either chemical (Brene et al., 1990; Xu et al., 1992) or mechanical lesions (Neve et al., 1991) resulted in increases in both dopaminergic receptors and the mRNA encoding for these receptors. Similarly, axotomy of facial motoneurons changed the levels of mRNA encoding nicotinic receptors: mRNA encoding $\alpha_{3}$ decreased while mRNA encoding $\beta_{2}$ increased (Senba et al., 1990). These observations, coupled with the observations made in the present study, indicate that regulation of mRNA encoding for neurotransmitter receptors differs between drug-treated and denervated tissue.

The experiments described in the present study used cRNA probes isolated from rat to measure $\mathrm{mRNA}$ levels in mice. Since cross-species probes were used, these probes were synthesized 
Table 8. Quantitation of relative hybridization of cRNA transcribed from pPC989 $\left(\alpha_{5}\right)$ in control and nicotine-treated mice

\begin{tabular}{|c|c|c|c|}
\hline & Control & Treated & $t$ \\
\hline \multicolumn{4}{|l|}{ Telencephalon } \\
\hline \multicolumn{4}{|l|}{ 1. Neocortex } \\
\hline Cerebral cortex (deep) & $289.2+26.5$ & $298.0 \pm 17.2$ & 0.28 \\
\hline \multicolumn{4}{|l|}{ 2. Rhinencephalon } \\
\hline Dentate gyrus & $193.3 \pm 14.7$ & $209.2 \pm 23.0$ & 0.58 \\
\hline Hippocampus & $64.4 \pm 9.7$ & $62.6 \pm 6.3$ & 0.16 \\
\hline Subiculum & $350.7 \pm 50.2$ & $457.8 \pm 76.5$ & 1.17 \\
\hline \multicolumn{4}{|l|}{ 3. Basal ganglia } \\
\hline Caudate putamen & $70.2 \pm 9.8$ & $90.3 \pm 25.6$ & 0.73 \\
\hline Substantia nigra & $417.3 \pm 32.6$ & $484.3 \pm 31.8$ & 1.47 \\
\hline \multicolumn{4}{|l|}{ Diencephalon } \\
\hline \multicolumn{4}{|c|}{ 1. Epithalamus and subthalamus } \\
\hline Medial habenula & $238.3 \pm 15.9$ & $219.7 \pm 8.4$ & 1.03 \\
\hline \multicolumn{4}{|l|}{ Mesencephalon } \\
\hline Interpeduncular $\mathrm{n}$. & $1421.0 \pm 159.9$ & $1638.8 \pm 148.2$ & 1.00 \\
\hline Ventral tegmental area & $71.9 \pm 12.1$ & $67.5 \pm 13.3$ & 0.24 \\
\hline \multicolumn{4}{|l|}{ Pons } \\
\hline Dorsal tegmental $\mathrm{n}$. & $874.6 \pm 129.1$ & $1196.0 \pm 368.9$ & 1.05 \\
\hline Pyramidal tract & $257.3 \pm 18.5$ & $258.6 \pm 19.2$ & 0.05 \\
\hline
\end{tabular}

Data show hybridization of ${ }^{35}$ S-cRNA for $\alpha_{s}$ in various brain regions from animals that were infused chronically with saline (control; $n=6$ ) or nicotine (treated; $4.0 \mathrm{mg} / \mathrm{kg} / \mathrm{hr}$ nicotine; $n=6$ ) for $10 \mathrm{~d}$. Quantitative autoradiography was performed as described in Materials and Methods. The groups were compared by $t$ test. No significant effects of treatment were observed. Hybridization measured in hippocampus, caudate putamen, and ventral tegmental area represents background hybridization, and the signals do not differ from film background.

to hybridize with the full coding region of each of the mRNA subunits measured. This strategy was employed to maximize the ability to detect mRNA that may differ between rat and mouse. Since full-length probes were used, the possibility of cross-hybridization between a specific probe and other, similar, mRNA species was possible. To minimize this possibility, hybridizations and washes were conducted under very high-stringency conditions. In addition, control experiments indicated that the signals obtained after additional washes at higher stringency were comparable to the signals obtained after the initial washes for every probe except that for $\alpha_{2}$, as indicated in the Results.

The relative intensity of the hybridization observed using the rat $\beta_{2}$-probe in mouse brain was much lower than that observed with the rat $\alpha_{4}$-probe in mouse brain. In addition, less variation in signal intensity among brain areas was observed with the $\beta_{2}$ probe than with the $\alpha_{4}$-probe. To determine if a misleading hybridization pattern was obtained by using a cross-species probe, two different $\beta_{2}$-clones were isolated from a mouse brain library and the patterns of hybridization obtained with these probes were compared to that obtained with the rat probe. The pattern of hybridization was the same for all three probes, but the intensity of the signals obtained with the mouse probes was greater than that obtained using the rat probe. Nevertheless, the results indicated that the rat probe used in the present study was adequate for the analysis of relative levels of mRNA for mouse $\beta_{2}$.

The results presented in the present article indicate that the distribution of mRNA encoding four $\alpha$-subunits of nicotinic cholinergic receptors in mouse brain are, in general, similar to those previously reported for rat brain (Wada et al., 1989; Boulter et al., 1990), but that some qualitative and quantitative differences in the distribution of mRNA for several of these nicotinic subunits may exist. Since the experimental conditions employed for the hybridization experiments with the two species were different, detailed comparisons at the present time may be misleading. A direct comparison of the hybridization patterns for the neuronal nicotinic receptor subunit mRNAs in rat and mouse brain would be valuable.

In summary, the results presented in this article strongly suggest that the steady-state increase in nicotinic receptors that bind $\mathrm{L}-^{3} \mathrm{H}$-nicotine with high affinity that occurs with chronic nicotine treatment does not result from an increase in the amount of mRNA encoding any one of four $\alpha$-subunits or from a change in a widely expressed $\beta$-subunit $\left(\beta_{2}\right)$ of the nicotinic cholinergic receptors, although regulation of receptor level by changes in the levels of RNA encoding other nicotinic subunits has not yet been investigated. If $\mathrm{L}^{-3} \mathrm{H}$-nicotine binding measures nicotinic receptors composed of $\alpha_{4}$ - and $\beta_{2}$-subunits, it seems likely that regulation of receptor increases that occur with chronic nicotine treatment occurs posttranscriptionally.

\section{References}

Barr JE, Holmes DB, Ryan LM, Sharpless SH (1979) Techniques for the chronic cannulation of the jugular vein in mice. Pharmacol Biochem Behav 11:115-118.

Benwell MEM, Balfour DJK, Anderson JM (1988) Evidence that tobacco smoking increases the density of $(-)-\left[{ }^{3} \mathrm{H}\right]$ nicotine binding sitcs in human brain. J Neurochem 50:1243-1247.

Boulter J, Evans K, Goldman D, Martin G, Treco D, Heinemann S, Patrick J (1986) Isolation of a cDNA clone coding for a possible neural nicotinic receptor $\alpha$-subunit. Nature 319:368-374.

Boulter J, Connelly J, Deneris E, Goldman D, Heinemann S, Patrick J (1987) Functional expression of two neuronal nicotinic acetylcholine receptors from cDNA clones identifies a gene family. Proc Natl Acad Sci USA 84:7763-7767. 
Boulter J, O'Shea-Greenfield A, Duvoisin RM, Connolly JG, Wada E, Jensen A, Gardner PD, Ballivet M, Deneris ES, McKinnon D, Heinemann S, Patrick J (1990) $\alpha 3, \alpha 5$ and $\beta 4$ : three members of the rat neuronal nicotinic acetylcholine receptor-related gene family form a gene cluster. J Biol Chem 265:4472-4482.

Brene S, Lindefors N, Herrera-Marschitz M, Persson H (1990) Expression of dopamine D2 receptor and choline acetyltransferase mRNA in the dopamine deafferented rat caudate-putamen. Exp Brain Res 83:96-104.

Chomczynski P, Sacchi N (1987) Single-step method of RNA isolation by acid guanidinium thiocyanate-phenol-chloroform extraction. Anal Biochem 162:156-159.

Clarke PBS, Schwartz RD, Paul SM, Pert CB, Pert A (1985) Nicotinic binding in rat brain: autoradiographic comparison of $\left[{ }^{3} \mathrm{H}\right]$ acetylcholine, $\left[{ }^{3} \mathrm{H}\right]$ nicotine and [125I]bungarotoxin. J Neurosci 5:1307-1315.

Couturier S, Bertrand D, Matter J-M, Hernandez M-C, Bertrand S, Millar N, Valera S, Barkas T, Ballivet M (1990) A neuronal nicotinic acetylcholine receptor subunit $(\alpha 7)$ is developmentally regulated and forms a homo-oligomeric channel blocked by a-BTX. Neuron 5:847856.

Cox KH, DeLeon LM, Angerer LM, Angerer RC (1984) Detection of mRNAs in sea urchin embryos by in situ hybridization using asymmetric RNA probes. Dev Biol 101:485-502.

Deneris ES, Connolly J, Boulter J, Wada E, Wada K, Swanson LW, Patrick J, Heinemann S (1988) Primary structure and expression of $\beta 2$ : a novel subunit of neuronal nicotinic receptors. Neuron 1:45-54.

Deneris ES, Boulter J, Patrick J, Swanson LW, Heinemann S (1989) $\beta 3$ : a new member of nicotinic acetylcholine receptor gene family is expressed in brain. J Biol Chem 264:6268-6272.

Duvoisin RM, Deneris ES, Boulter J, Patrick J, Heinemann S (1989) The functional diversity of the neuronal nicotinic acetylcholine receptors is increased by a novel subunit: $\beta 4$. Neuron 3:487-496.

Flores CM, Rogers SW, Pabreza LA, Wolfe BB, Kellar KJ (1992) A subtype of nicotinic cholinergic receptor in rat brain is composed of $\alpha 4$ and $\beta 2$ subunits and is up-regulated by chronic nicotine treatment. Mol Pharmacol 41:31-37.

Goldman D, Deneris E, Luyten W, Kochhar A, Patrick J, Heinemann S (1987) Members of a nicotinic receptor gene family are expressed in different regions of the mammalian central nervous system. Cell 48:965-973.

Kellar KJ, Giblin BA, Lumpkin MD (1989) Regulation of brain cholinergic sites by nicotine. Prog Brain Res 79:209-216.

Lee JJ, Costlow NA (1987) A molecular titration assay to measure transcript prevalence levels. Methods Enzymol 152:633-649.

Lindstrom J, Schoepfer R, Conroy WG, Whiting P (1990) Structural and functional heterogeneity of nicotinic receptors. In: The biology of nicotine dependence. CIBA Found Symp 152:23-52.

Lowry OH, Rosebrough NH, Farr AC, Randall RJ (1951) Protein measurement with the Folin phenol reagent. J Biol Chem 193:265275.

Luetje CW, Patrick J, Seguela P (1990) Nicotine receptors in mammalian brain. FASEB J 4:2753-2760.

Marks MJ, Collins AC (1982) Characterization of nicotine binding in mouse brain and comparison with the binding of alpha-bungarotoxin and quiliculidinyl benzilate. Mol Pharmacol 22:554-564.

Marks MJ, Burch JB, Collins AC (1983) Effects of chronic nicotine infusion on tolerance development and cholinergic receptors. J Pharmacol Exp Ther 226:806-816.

Marks MJ, Stitzel JA, Collins AC (1985) Time course study of the effects of chronic nicotine infusion on drug response and brain receptors. J Pharmacol Exp Ther 235:619-628.

Marks MJ, Stitzel JA, Collins AC. (1986a) Dose-response analysis of nicotine tolerance and receptor changes in two inbred mouse strains. J Pharmacol Exp Ther 239:358-364.

Marks MJ, Stitzel JA, Romm E, Wehner JM, Collins AC (1986b)
Nicotinic binding sites in rat and mouse brain: comparison of acetylcholine, nicotine and alpha-bungarotoxin. Mol Pharmacol 30:427436.

Marks MJ, Stitzel JA, Collins AC (1989) Genetic influences on nicotine responses. Pharmacol Biochem Behav 33:667-678.

Neve KA, Neve RL, Fidel S, Janowsky A, Higgins GA (1991) Increased abundance of alternatively spliced forms of D2 dopamine receptor mRNA after denervation. Proc Natl Acad Sci USA 88:28022806.

Papke RL, Boulter J, Patrick J, Heinemann S (1989) Single channel currents of rat neuronal nicotinic acetylcholine receptors expressed in Xenopus oocyles. Neuron 3:589-596.

Pauly JR, Stitzel JA, Marks MJ, Collins AC (1989) An autoradiographic analysis of cholinergic receptors in mouse brain. Brain Res Bull 22:453-459.

Pauly JR, Marks MJ, Gross SD, Collins AC (1991) An autoradiographic analysis of cholinergic receptors in mouse brain after chronic nicotine treatment. J Pharmacol Exp Ther 258:1127-1136.

Romano C, Goldstein AM (1980) Stereospecific nicotine receptors in rat brain. Science 210:647-649.

Schoepfer R, Conroy WG, Whiting P, Gore M, Lindstrom J (1990) Brain alpha-bungarotoxin binding protein cDNAs and MAbs reveal subtypes of this branch of ligand-gated ion channel gene superfamily. Neuron 5:35-48.

Schwartz RC, Kellar KJ (1983) Nicotinic cholinergic receptor binding sites in the brain; regulation in vivo. Science 220:214-216.

Senba E, Simmons DM, Wada E, Wada K, Swanson LW (1990) RNA levels of neuronal nicotinic acetylcholine receptor subunits are differentially regulated in axotomized facial motoneurons: an in situ hybridization study. Mol Brain Res 8:349-353.

Simmons DM, Arriza JL, Swanson LW (1989) A complete protocol for in situ hybridization of messenger RNAs in brain and other tissues with radiolabeled single-stranded RNA probes. J Histotechnol 12: $169-181$.

Surgeon General (U.S. Department of Health and Human Services) (1988) The health consequences of smoking: nicotine addiction. A report of the Surgcon Gencral. DHHS publication number (CDC) 888406. Rockville, MD: Public Health Service Office on Smoking and Health.

Swanson LW, Simmons DM, Whiting PW, Lindstrom J (1987) Immunohistochemical localization of neuronal nicotinic receptors in rodent central nervous system. J Neurosci 7:3334-3342.

van Tol HHM, Riva M, Civelli O, Creese I (1990) Lack of effect of chronic dopamine receptor blockade on $\mathrm{D}_{2}$ dopamine receptor $\mathrm{mRNA}$ level. Neurosci Lett 111:303-308.

Wada E, Wada K, Boulter J, Deneris E, Heinemann S, Patrick J, Swanson LW (1989) Distribution of $\alpha 2, \alpha 3, \alpha 4$ and $\beta 2$ neuronal nicotinic receptor subunit mRNAs in the central nervous system: a hybridization histochemical study in the rat. J Comp Neurol 284:314-335.

Wada K, Ballivet M, Boulter J, Connolly J, Wada E, Deneris ES, Swanson LW, Heincmann S, Patrick J (1988) Functional expression of a new pharmacological subtype of brain nicotinic acetylcholine receptor. Science 240:330-334.

Whiting P, Lindstrom J (1986) Pharmacological properties of immunoisolated neuronal nicotinic receptors. J Neurosci 6:3061-3069.

Whiting P, Esch F, Shimasaki S, Lindstrom J (1987) Neuronal nicotinic acetylcholine receptor $\beta$-subunit is coded for by cDNA for $\alpha 4$. FEBS Lett 219:459-463.

Whiting P, Schoepfer R, Lindstrom J, Priestley T (1991) Structural and pharmacological characterization of the major brain nicotinic acetylcholine receptor subtype stably expressed in mouse fibroblasts. Mol Pharmacol 40:463-472.

$\mathrm{Xu} \mathrm{S}$, Monsma FJ, Sibley DR, Creese I (1992) Regulation of $\mathrm{D}_{1 \mathrm{~A}}$ and $\mathrm{D}_{2}$ dopamine receptor $\mathrm{mRNA}$ during ontogenesis, lesion and chronic antagonist treatment. Life Sci 50:383-396. 